УДК 634.8.03

03.00.00 Биологические науки

ОСОБЕННОСТИ ПРОЯВЛЕНИЯ
РЕГЕНЕРАЦИОННОЙ АКТИВНОСТИ У
ЧЕРЕНКОВ ПОДВОЙНЫХ
ФИЛЛОКСЕРОУСТОЙЧИВЫХ СОРТОВ
ВИНОГРАДА ПОД ВЛИЯНИЕМ ОБРАБОТКИ
ИХ ГЕТЕРОАУКСИНОМ

Радчевский Петр Пантелеевич

канд. с.-х. наук, профессор кафедры

виноградарства

SPIN-код 1807-2710

e-mail radchevskii@rambler.ru

Кубанский государственный аграрный

университет, Краснодар, Россия

В работе излагаются результаты исследований по изучению влияния обработки черенков подвойных филлоксероустойчивых сортов винограда растворами гетероауксина на их регенерационные свойства. Предварительные опыты были проведены в 1986 г. во ВНИИВиВ им. Я.И. Потапенко на черенках трех сортов винограда - Берландиери х Рипариа Кобер 5ББ, Рипариа х Рупестрис 101-14 и Берландиери х Рипариа СО-4. Черенки, замоченные в течение 48 ч в $0,005 \%$-ном растворе гетероауксина укореняли в песке в регулируемых условиях температуры, влажности и аэрации. Опыты были продолжены в 2012-2013 гг. в Кубанском ГАУ. Здесь к перечисленным выше сортам были добавлены Гравесак, РСБ и Берландиери х Рипариа Телеки 5Ц. Трехглазковые черенки проращивали во влажных пропаренных опилках в пленочной теплице. В предварительных исследованиях применение гетероауксина позволило увеличить укореняемость на 20,3-40,0 \%. Наибольшее увеличение укореняемости (40 \%) наблюдалось на сорте СО-4, характеризующемся самой слабой потенциальной ризогенной активностью, а наименьшее (20,3 \%) на контрольном сорте Кобер 5 ББ. В последующих исследованиях обработка базальных концов черенков 0,01\%-ным раствором гетероауксина в значительной степени способствовала активизации в них регенерационных процессов, что выразилось в: увеличении длины побегов - на сортах 5 Ц, 10114 и Гравесак на 23,1-157,6 \%; увеличении укореняемости черенков от $16,7 \%$ на сорте 5 Ц до $60,0 \%$ на сорте Кобер 5ББ, а количества черенков имеющих не менее трех корней, соответственно, от $13,0 \%$ до 54,7 \%; увеличении числа корней от 0,7 шт. на сорте CO-4, до 2,7 шт. на сорте 101-14 или в 1,7-2,7 раза. Лишь на сорте РСБ применение гетероауксина не привело к положительным результатам, что можно объяснить сортовыми особенностями
UDC 634.8 .03

Biological sciences

\section{THE PECULIARITIES OF REGENERATION \\ ACTIVITY OF WILDING CUTTINGS OF PHYLLOXERARESISTANT VARIETYS OF GRAPES INFLUENCED BY HETEROAUXIN TREATMENT}

Radchevsky Petr Panteleevich

Cand.Agr.Sci., professor of the Viticulture department

RSCI SPIN-code 1807-2710

e-mail radchevskii@rambler.ru

Kuban State Agrarian University, Krasnodar, Russia

The research results on regeneration activity of wilding cuttings of phylloxeraresistant varieties of grapes influenced by heteroauxin treatment are analysed in the article. The preliminary studies were held in All-Russian research institute of viticulture and wine-making of Ya.I. Potapenko using cuttings of 3 grape varieties - Berlandieri x Riparia Cober 5bb, Riparia x Rupestris 101-14 and Berlandieri x Riparia CO-4. The cuttings were soaked during 48 hours in $0,005 \%$ heteroauxin and were implanted in sand in adjustable conditions of temperature, humidity and aeration. In 2012-2013 experiments were continued in Kuban State Agrarian University. The varieties Gravesak, RSB and Berlandieri x Riparia Teleki 5C were added to the experiment. Three-items buds were shooted in damp steamed sawdust in a film hothouse. In preliminary researches application of heteroauxin has allowed to increase root-growing by $20,3-40,0 \%$. The greatest increase of root-growing $(40 \%)$ was observed on variety $\mathrm{CO}-4$, that is characterized by the weakest potential rhizogenesis activity, and the least $(20,3 \%)$ on control variety Cober 5 bb. Next researches show that treatment of cuttings basal ends by $0,01 \%$ heteroauxin activated their regeneration process, that was expressed in: increase in sprouts length - variety $5 \mathrm{C}, 101-14$ and Gravesak by 23,1 $157,6 \%$; increasing of cuttings root-growing from $16,7 \%$ on variety $5 \mathrm{C}$ to $60,0 \%$ on variety Cober $5 \mathrm{bb}$, the quantity of cuttings with not fewer of 3 roots from accordingly $13,0 \%$ to $54,7 \%$; increasing of roots from 0,7 on variety CO-4 to 2,7 on variety $101-14$ or in 1,7-2,7 times. The application of heteroauxin on variety RSB did not show positive results, because of the variety peculiarities 
Ключевые слова: ВИНОГРАД, РЕГУЛЯТОРЫ РОСТА, ГЕТЕРОАУКСИН, ГОРМОНАЛЬНАЯ АКТИВНОСТЬ, РАСПУСКАНИЕ ГЛАЗКОВ, УКОРЕНЯЕМОСТЬ, РИЗОГЕННАЯ АКТИВНОСТЬ, КОРНИ

Doi: 10.21515/1990-4665-123-102
Keywords: GRAPE, GROWTH REGULATORS, HETEROAUXIN, HORMONAL ACTIVITY, BLOOMING OF BUDS, ROOT-GROWING, RHIZOGENESIS ACTIVITY, ROOTS

\section{Введение}

Наибольшее применение в практике виноградарства для стимулирования корнеобразовательной способности черенков нашел гетероауксин. Однако, до сих пор слабым местом является вопрос его использования с учетом биологических особенностей сортов винограда, в первую очередь потенциальной ризогенной активности черенков. Причем, поскольку ведущей в крае является привитая культура винограда, представляет практический интерес изучение этого вопроса на черенках подвойных сортов, в том числе тех, которые были введены в стандартный сортимент сравнительно недавно.

В связи с этим целью наших исследований явилось изучение обработки черенков подвойных филлоксероустойчивых сортов винограда гетероауксином на их регенерационные свойства в зависимости от сортовых особенностей.

\section{Материалы и объекты исследования}

Исследования по данному вопросу были начаты в 1986 г. в ВНИИВиВ им. Я.И. Потапенко на двуглазковых черенках подвойных филлоксероустойчивых сортов винограда Берландиери х Рипариа Кобер 5ББ (Кобер 5ББ), Рипариа х Рупестрис 101-14 (101-14) и Берландиери х Рипариа CO-4 (CO-4). Затем они были продолжены в 2011-2012 гг. в Кубанском ГАУ, где количество подвойных сортов было расширено до шести. Кроме уже упоминавшихся сортов Кобер 5ББ, 101-14 и СО-4 в опыт были включены новые районированные сорта - Гравесак, РСБ и перспективный - Берландиери х Рипариа Телеки 5Ц (5Ц). 
Подвои Кобер 5 ББ, СО-4 и 5Ц относятся к группе америкоамериканских межвидовых гибридов Берландиери х Рипариа, а 101-14 - к группе межвидовых гибридов Рипариа х Рупестрис. Хотя в родословной подвоя Гравесак и присутствует вид Берландиери - по морфологическим признакам и регенерационной активности он стоит ближе к группе Рипариа х Рупестрис [8,42].

В КубГАУ опыт был проведен на трехглазковых черенках.

\section{Методика исследований}

В опыте, проведенном во ВНИИВиВ им. Я.И. Потапенко в конце второй декады февраля черенки сортов Кобер 5ББ, 101-14 и СО-4 были нарезаны на 2-х глазковые и замочены на двое суток в воде (контроль) и в 0,005\%-ном растворе гетероауксина (опытный вариант). После обработки черенки были высажены на проращивание в ящики с песком, которые поместили в СУВРы (стеллаж ускоренного выращивания растений). Учеты побего- и корнеобразования были сделаны на 15-й,18-й и 27-й дни опыта.

В исследованиях проведенных в КубГАУ заготовленные в декабреянваре на маточнике подвойных лоз АФ «Фанагория-Агро» и хранившиеся в холодильнике при температуре $0-4{ }^{\circ} \mathrm{C}$ черенки в начале второй половины апреля были нарезаны на трехглазковые и замочены в течение 24 часов в воде. После подсушивания с поверхности они были покрыты в верхней части антитранспирантом, при температуре около $90^{\circ} \mathrm{C}$. Затем по 40 черенков каждого сорта были помещены нижними концами на 24 часа в 0,01\%-ный раствор гетероауксина. Черенки контрольного варианта были помещены в воду. После обработки пучки черенков с тщательно выровненными нижними концами были установлены на укоренение во влажные пропаренные опилки на обогреваемом стеллаже в пленочной обогреваемой теплице. Температуру опилок в нижней части черенков 
поддерживали с помощью специального датчика на уровне $25-27^{\circ} \mathrm{C}$. Влажность опилок сохраняли путем регулярных поливов теплой водой.

Повторность опыта четырехкратная (по 10 черенков в повторности).

При проведении исследований пользовались методикой, которая была освещена нами в совместной работе с Л.М. Малтабаром и Н.Д. Магомедовым [9], а затем усовершенствована и изложена как в самостоятельных публикациях, так и сделанных в соавторстве [16-39].

В исследованиях были выполнены следующие учеты, анализы и наблюдения:

а) при укоренении черенков на воде:

1. Учет распускания глазков на черенках в динамике;

2. Учет количества укоренившихся черенков в динамике;

3. Учет количества корней, образовавшихся на черенках в динамике;

На основании полученных экспериментальных данных вычисляли:

- процент черенков с распустившимися глазками;

- укореняемость (процент черенков с корнями);

- среднее число корней на черенок.

б) при укоренении черенков в опилках:

1. Учет количества черенков с распустившимися глазками;

2. Измерение длины зеленых побегов;

3. Учет количества укоренившихся черенков;

4. Учет количества корней на базальной части черенков;

5. Учет количества черенков имеющих не менее трех корней.

Статистическую обработку экспериментальных данных поводили методом дисперсионного и корреляционного анализов с помощью компьютерных программ Statistica 6,0; Bas и STAT-VGA. 


\section{Результаты исследований}

В исследованиях, проведенных во ВНИИВиВ им. Я.И. Потапенко наибольшей активностью распускания глазков выделялся сорт Кобер 5 ББ, за которым следовал 101-14. У сорта СО-4 к концу опыта распустилось только 25,0 \% глазков, при 88,2 \% у сорта Кобер 5 ББ и 63,2 \% у сорта 10114. Это может свидетельствовать о более глубоком периоде покоя у последнего сорта по сравнению с двумя первыми. На всех трех сортах обработка черенков гетероауксином привела к ингибированию распускания глазков (таблица 1). Если на 27-й день опыта в контрольных вариантах распустилось от 25,0 \% (CO-4) до 88,2 \% (Кобер 5 ББ) глазков, то в опытных - от 15,0 до $66,7 \%$. Уменьшение анализируемого показателя составило от $10 \%$ на сорте СО-4, до 21,5 \% на сорте Кобер 5ББ.

Таблица 1 - Динамика распускания глазков на черенках подвойных сортов винограда в зависимости от сортовых особенностей. Новочеркасск, ВНИИВиВ им. Я.И.

Потапенко, 1986 г.

\begin{tabular}{|l|l|c|c|c|}
\hline \multirow{2}{*}{ Сорт } & \multirow{2}{*}{ Вариант } & \multicolumn{3}{|c|}{ Черенков с распустившимся глазком, \% } \\
\cline { 3 - 5 } & & 15 день & 18 день & 27 день \\
\hline \multirow{2}{*}{$\begin{array}{l}\text { Кобер 5 ББ } \\
\text { (контроль) }\end{array}$} & контроль & 88,2 & 88,2 & 88,2 \\
\cline { 2 - 5 } гетероауксин & 33,3 & 38,9 & 66,7 \\
\hline \multirow{2}{*}{ СО-14 } & контроль & 57,9 & 63,2 & 63,2 \\
\cline { 2 - 5 } & гетероауксин & 14,3 & 21,4 & 50,0 \\
\cline { 2 - 5 } & контроль & 5,0 & 5,0 & 25,0 \\
\cline { 2 - 5 } & гетероауксин & - & 10,0 & 15,0 \\
\hline
\end{tabular}

В то же время применение гетероауксина способствовало значительному увеличению укореняемости (таблица 2).

Так, если на 18-й день опыта в контрольном варианте у сортов Кобер 5 ББ и СО-4 было только 5,9 и 5,0 \% укорененных черенков, то в опытном их оказалось уже 33,3 и 25,0 \%. Увеличение укореняемости составило 27,4 и 20,0 \%. На сорте 101-14, где в контрольном варианте на этот срок отмечена наибольшая укореняемость, в опытном она достигла 64,3\%, превысив контроль на 16,9\%. 
Таблица 2 - Динамика укореняемости черенков подвойных сортов винограда в зависимости

от сортовых особенностей. Новочеркасск, ВНИИВиВ им. Я.И. Потапенко, 1986г.

\begin{tabular}{|l|l|c|c|}
\hline \multirow{2}{*}{ Сорт } & \multirow{2}{*}{ Вариант } & \multicolumn{2}{|c|}{ Укореняемость, \% } \\
\cline { 3 - 4 } & & 18 день & 27 день \\
\hline \multirow{2}{*}{$\begin{array}{l}\text { Кобер 5 ББ } \\
\text { контроль) }\end{array}$} & контроль & 5,9 & 35,3 \\
\cline { 2 - 4 } & гетероауксин & 33,3 & 55,6 \\
\hline \multirow{2}{*}{ СО-14 } & контроль & 47,4 & 52,6 \\
\cline { 2 - 4 } & гетероауксин & 64,3 & 85,7 \\
\cline { 2 - 4 } & контроль & 5,0 & 20,0 \\
\cline { 2 - 4 } & гетероауксин & 25,0 & 60,0 \\
\hline
\end{tabular}

Так, если на 18-й день опыта в контрольном варианте у сортов Кобер 5 ББ и СО-4 было только 5,9 и 5,0 \% укорененных черенков, то в опытном их оказалось уже 33,3 и 25,0 \%. Увеличение укореняемости составило 27,4 и 20,0 \%. На сорте 101-14, где в контрольном варианте на этот срок отмечена наибольшая укореняемость, в опытном она достигла 64,3\%, превысив контроль на 16,9\%.

Если в контрольном варианте укореняемость к концу опыта колебалась от 20,0 \% на сорте СО-4 до 52, \% на сорте 101-14, то в опытном - от 55,6 \% на сорте Кобер 5 ББ до 85,7 \% на сорте 101-14. Наибольшее увеличение укореняемости (40 \%) произошло на сорте CO-4, характеризующемся самой слабой потенциальной ризогенной активностью, а наименьшее (20,3 \%) на контрольном сорте Кобер 5 ББ. На сорте 101-14, с самой высокой потенциальной ризогенной активностью, увеличение укореняемости составило $33,1 \%$.

Таким образом, в наших исследованиях самой высокой потенциальной ризогенной активностью характеризовался сорт 101-14, а самой низкой - CO-4. Аналогичные результаты получены и другими исследователями, проводившими свои опыты в различных почвенноклиматических условиях $[3,6,8,10,13,14,41,43]$. 
Ф.А. Гудумак [4] объясняет более слабую ризогенную активность черенков сорта CO-4 тем, что в условиях Молдовы из-за сильного роста побегов у него получаются длинные междоузлия, нередко рыхлая древесина и большая сердцевина. Все это приводит к уменьшению регенерационной активности черенков и снижению выхода саженцев привитых на нем сортов.

Что касается количества образовавшихся на базальных концах черенков корней, то на сорте Кобер 5 ББ применение гетероауксина не оказало на этот показатель никакого влияния (таблица 3). В обоих вариантах оно было практически одинаковым. На сорте 101-14 произошло увеличение количества корней на 0,8 шт. или на 40,0 \%, а на сорте CO-4 оно увеличилось на 1,2 шт., то есть в 2 раза.

Таким образом, замачивание подвойных черенков сортов Кобер 5 ББ, 101-14 и СО-4 в течение 2-х суток в 0,005 \%-ном растворе гетероауксина приводит К ингибированию распускания глазков, увеличению укореняемости (на 20,3-40,0 \%), а на сортах 101-14 и СО-4 - увеличению числа пяточных корней (на 40 и $100 \%$ ).

Таблица 3 - Динамика образования корней на черенках подвойных сортов винограда в зависимости от сортовых особенностей. Новочеркасск, ВНИИВиВ им. Я.И. Потапенко, 1986 г.

\begin{tabular}{|l|l|c|c|}
\hline \multirow{2}{*}{ Сорт } & \multirow{2}{*}{ Вариант } & \multicolumn{2}{|c|}{ Корней на черенок, шт. } \\
\cline { 3 - 4 } & & 18 день & 27 день \\
\hline \multirow{2}{*}{ Кобер 5 ББ } & Контроль & 3,0 & 2,2 \\
\cline { 2 - 4 } & Гетероауксин & 2,8 & 2,3 \\
\hline \multirow{2}{*}{ СО1-14 } & Контроль & 1,9 & 2,0 \\
\cline { 2 - 4 } & гетероауксин & 2,7 & 2,8 \\
\hline & Контроль & 1,0 & 1,2 \\
\cline { 2 - 4 } & Гетероауксин & 2,2 & 2,4 \\
\hline
\end{tabular}

Максимальное увеличение укореняемости и числа пяточных корней под влиянием гетероауксина наблюдалось на сорте СО-4, отличающемся слабой потенциальной ризогенной активностью черенков, а минимальное - 
на Кобере 5 ББ, черенки которого показали среднюю ризогенную активность.

Продолжение эксперимента с применением гетероауксина уже в Кубанском госагроуниверситете на шести подвойных сортах показало, что в 2011г.в контрольном варианте максимальный процент черенков с распустившимися глазками (100\%) наблюдался на сортах РСБ и 5Ц (таблица 4).

Таблица 4 - Степень распускания глазков на черенках подвойных филлоксероустойчивых сортов винограда под влиянием обработки их гетероауксином

\begin{tabular}{|c|c|c|c|c|}
\hline \multirow[t]{2}{*}{ Сорт } & \multirow[t]{2}{*}{ Вариант } & \multicolumn{3}{|c|}{$\begin{array}{c}\text { Черенков с распустившимися } \\
\text { глазками, } \\
\%\end{array}$} \\
\hline & & 2011 г. & 2012 г. & $\begin{array}{c}\text { среднее за } \\
2011-2012 \text { гг. }\end{array}$ \\
\hline \multirow[t]{2}{*}{ Кобер 5ББ } & контроль & 93,3 & 92,5 & 92,9 \\
\hline & гетероауксин & 86,7 & 80,0 & 83,4 \\
\hline \multirow[t]{2}{*}{$101-14$} & контроль & 86,7 & 97,5 & 92,1 \\
\hline & гетероауксин & 100 & 82,5 & 91,2 \\
\hline \multirow[t]{2}{*}{$\mathrm{CO}-4$} & контроль & 93,3 & 95,0 & 94,2 \\
\hline & гетероауксин & 90,0 & 97,5 & 93,8 \\
\hline \multirow[t]{2}{*}{ Гравесак } & контроль & 86,7 & 77,5 & 82,1 \\
\hline & гетероауксин & 90,0 & 95,0 & 92,5 \\
\hline \multirow[t]{2}{*}{ РСБ } & контроль & 100 & 80,0 & 90,0 \\
\hline & гетероауксин & 100 & 97,5 & 98,8 \\
\hline \multirow[t]{2}{*}{$5 Ц$} & контроль & 100 & 80,0 & 90,0 \\
\hline & \begin{tabular}{|l|} 
гетероауксин \\
\end{tabular} & 93,3 & 67,5 & 80,4 \\
\hline \multirow{2}{*}{ Среднее по опыту } & контроль & 93,3 & 86,7 & 90,2 \\
\hline & гетероауксин & 93,3 & 86,7 & 90,0 \\
\hline \multicolumn{2}{|l|}{$\mathrm{HCP}_{01}$ (сорта -фактор А) } & 6,41 & 6,24 & 4,36 \\
\hline \multicolumn{2}{|c|}{$\mathrm{HCP}_{11}($ ФАВ - фактор Б) } & 3,70 & 3,60 & 252 \\
\hline \multicolumn{2}{|c|}{$\mathrm{HCP}_{01}$ (взаимодействие факторов - АБ) } & 9,07 & 8,82 & 6,17 \\
\hline
\end{tabular}

Разница между этими двумя сортами и остальными четырьмя составляла 6,7- 13,3 \%, то есть была достоверной, так как $\mathrm{HCP}_{01}=6,41 \%$. Наименьшее значение данного показателя отмечено на сортах 101-14 и Гравесак. Разница между этими сортами и остальными четырьмя равнялась 6,6-13,3\% и также была достоверной. 
По величине анализируемого показателя в 2011г испытываемые сорта можно разделить на три группы: РСБ и 5Ц (глазки распустились у $100 \%$ черенков), Кобер 5 ББ и СО-4 (93,3 \%) и 101-14 и Гравесак - 86,7 \%.

В 2012 г. ситуация по степени распускания на черенках в значительной степени отличалась от предыдущего года. Так максимальное количество черенков с распустившимися глазками $(97,5 \%)$ отмечено на сорте 101-14, у которого в предыдущем году данный показатель имел наименьшее значение.

Далее следовал сорт СО-4, у которого значение показателя было несколько ниже и составляло 95,0 \%, то есть примерно столько же, сколько и в предыдущем году. Почти не изменилась величина показателя по сравнению с предыдущим годом и на сорте Кобер 5 ББ.

На сортах РСБ и 5Ц, у которых в 2011 г. наблюдались максимальные значения показателя, в 2012 г. они уменьшились на $20 \%$ и составили $80 \%$. Наименьшее значение показателя $(77,5$ \%), так же, как и в предыдущем году, наблюдалось на сорте Гравесак. Данные статистического анализа показывают, что по величине анализируемого показателя изучаемые сорта в 2012 г. можно разделить на две группы: 1 группа - Кобер 5 ББ, СО-4 и 101-14, у которых глазки распустились на 92,5 - 97,5\% черенков и 2 группа - Гравесак, РСБ и 5Ц, у которых глазки распустились на 77,5 - 80,0 \% черенков. Разница между показателями обеих групп достоверна.

Из данных таблицы так же видно, что степень распускания глазков по годам зависела не только от сортовых особенностей, но и от физиологического состояния черенков.

В среднем по опыту в 2011 г. в контрольном варианте оказалось 93,3 \% черенков с распустившимися глазками, тогда как в 2012 г. - 86,7 \%, то есть на 6,6\% меньше.

В среднем за два года количество черенков с распустившимися глазками на пяти сортах из шести оказалось примерно одинаковым и 
находилось в пределах 90,0 - 94,2 \%, при $\mathrm{HCP}_{01}=4,36 \%$. В значительной степени от этой группы отличался только сорт Гравесак, у которого распустившиеся глазки наблюдались только на 82,1 \% черенков.

Обработка черенков гетероауксином оказала неоднозначное влияние на распускание глазков. Полученный эффект определялся как сортовыми особенностями, так и физиологическим состоянием черенков.

Достоверное уменьшение количества черенков с распустившимися глазками в оба года проведения исследований наблюдалось на сортах Кобер 5 ББ и СО-4, а также в 2012 г. на сорте 101-14. Причем на сортах Кобер 5 ББ и 5Ц в 2012 г. снижение показателя произошло на большую величину, чем в 2011 г.

На сорте 101-14 в 2011 г., а также на сортах Гравесак и РСБ в 2012 г. выявлено достоверное увеличение показателя. Разница при этом составляла от 13,4 до $17,5 \%$.

В остальных четырех случаях разницы между количеством черенков в контрольном и опытном варианте не было, или она оказалась недостоверной.

В среднем за 2 года выявлено достоверное уменьшение анализируемого показателя на сортах Кобер 5 ББ и СО-4 (на 9,5 - 9,6 \%), и увеличение на сортах Гравесак и РСБ (на $8,8-10,4 \%$ ).

Однако в среднем по опыту, как в отдельности по каждому году, так и в среднем за два года, значение показателя в контрольном и опытном вариантах было практически одинаковым.

Средняя длина побегов контрольного варианта колебалась в 2011 г. в пределах 3,3 - 7,3 см, а в 2012 г. - 3,4 - 5,6 см (таблица 5).

Максимальное значение показателя в оба года проведения исследований отмечено на сорте 101-14, а минимальное на сорте Гравесак. К сорту 101-14 в 2011 г. был близок сорт 5Ц. Разница между максимальной 
и минимальной длиной побегов, как в отдельности по каждому году, так и в среднем за два года достоверна.

Таблица 5 - Длина побегов на черенках подвойных филлоксероустойчивых сортов винограда под влиянием обработки их гетероауксином

\begin{tabular}{|c|c|c|c|c|}
\hline \multirow[t]{2}{*}{ Сорт } & \multirow[t]{2}{*}{ Вариант } & \multicolumn{3}{|c|}{ Длина побегов, см } \\
\hline & & 2011 г. & 2012 г. & $\begin{array}{c}\text { среднее за 2011- } \\
2012 \text { гг. }\end{array}$ \\
\hline \multirow[t]{2}{*}{ Кобер 5ББ } & контроль & 4,6 & 4,5 & 4,6 \\
\hline & гетероауксин & 5,3 & 6,0 & 5,6 \\
\hline \multirow[t]{2}{*}{$101-14$} & контроль & 7,3 & 5,6 & 6,4 \\
\hline & гетероауксин & 9,0 & 6,2 & 7,6 \\
\hline \multirow[t]{2}{*}{$\mathrm{CO}-4$} & контроль & 4,2 & 3,8 & 4,0 \\
\hline & гетероауксин & 3,0 & 3,5 & 3,2 \\
\hline \multirow[t]{2}{*}{ Гравесак } & контроль & 3,3 & 3,4 & 3,4 \\
\hline & гетероауксин & 8,5 & 6,9 & 7,7 \\
\hline \multirow[t]{2}{*}{ РСБ } & контроль & 4,9 & 4,0 & 4,4 \\
\hline & гетероауксин & 3,0 & 4,5 & 3,8 \\
\hline \multirow[t]{2}{*}{$5 Ц$} & контроль & 6,5 & 3,7 & 5,1 \\
\hline & гетероауксин & 7,9 & 3,0 & 5,4 \\
\hline \multirow{2}{*}{ Среднее по опыту } & контроль & 5,1 & 4,2 & 4,6 \\
\hline & гетероауксин & 6,1 & 5,0 & 5,6 \\
\hline \multicolumn{2}{|l|}{$\mathrm{HCP}_{01}$ (сорта -фактор A) } & 0,83 & 0,71 & 0,60 \\
\hline \multicolumn{2}{|l|}{$\mathrm{HCP}_{01}($ ФАВ - фактор Б) } & 0,48 & 0,41 & 0,35 \\
\hline \multicolumn{2}{|c|}{$\mathrm{HCP}_{01}$ (взаимодействие факторов - АБ) } & 1,18 & 1,0 & 0,85 \\
\hline
\end{tabular}

Достоверна была также разница между максимальными значениями 2011 и 2012 гг., и всеми остальными сортами, за исключением сорта 5Ц в 2011 г., где разница находилась в пределах ошибки опыта. Кроме этого достоверной оказалась разница между минимальным значением в 2011 г. (сорт Гравесак) и всеми остальными сортами. Незначительно отличалась от сорта Гравесак в 2012 г. длина побегов на сортах СО-4 и 5Ц.

В среднем за два года наибольшее значения длины побегов оказались у сортов 101-14 и 5Ц (6,4 и 5,1 см), а наименьшее - у сорта Гравесак $(3,4$ см). У остальных трех сортов они занимали промежуточное положение и находились в пределах 4,0 - 4,6 см.

Условия года по-разному сказались на величине анализируемого показателя. Так на сортах Кобер 5ББ и Гравесак в оба года длина побегов 
была практически одинаковой. На остальных четырех сортах в 2011 г. они были значительно больше, чем в 2012 г., что можно объяснить только разным физиологическим состоянием черенков, в первую очередь запасом пластических веществ. Особенно значительная разница наблюдалась на сортах 101-14 и 5Ц.

В целом по опыту в 2011 г. средняя длина побегов в контрольном варианте составила 5,1 см, а в 2012 г. - 4,2 см, т.е. была на 0,9 см меньше.

Обработка черенков гетероуксином в большинстве случаев привела к увеличению средней длины побегов. В 2011 г. увеличение показателя колебалось от 0,7 см на сорте Кобер 5ББ, до 5,2 см на сорте Гравесак, или от 15,2 до 157,6 \%. В 2012 г. длина побегов увеличилась от 0,5 см на сорте РСБ до 3,5 см на сорте Гравесак, или от 12,5 до 102,9 \%. Разница во всех случаях между контрольным и опытным вариантами была достоверной.

Таким образом, в оба года максимальное увеличение длины побегов в опытном варианте произошло на сорте Гравесак, у которого в контрольном варианте этот показатель был наименьшим. Как будет видно ниже, на этом сорте под влиянием гетероауксина произошло существенное увеличение количества корней, что и повлекло за собой значительное увеличение длины побегов. Приведенные нами ниже результаты дисперсионного анализа показывают на наличие достоверной корреляционной зависимости между количеством корней и длиной побегов.

У сорта СО-4 в оба года проведения исследований, а также у сорта РСБ в 2011 г. и сорта 5Ц в 2012 г. наблюдалось уменьшение средней длины побегов в опытном варианте. По нашему мнению, это можно объяснить сравнительно небольшим увеличением количества корней на черенках этих сортов в опытных вариантов. А на сорте РСБ в 2011 г. в варианте с гетероауксином даже наблюдалось уменьшение их количества. 
В среднем за два года достоверное увеличение средней длины побегов в опытном варианте произошло на трех сортах из шести - Кобер 5ББ, 101-14 и Гравесак. Превышение показателя по сравнению с контролем составило соответственно 1,$0 ; 1,2$ и 4,3 см или 21,$7 ; 18,8$ и 126,5 $\%$. На сорте 5Ц это увеличение оказалось недостоверным. На сортах CO-4 и РСБ средняя длина побегов в опытном варианте достоверно уменьшилась на 0,8 и 0,6 см или на 20,0 и $13,6 \%$.

В среднем по опыту длина побегов увеличилась в 2011 г. на 1,0 см $(19,6 \%)$, в 2012 г. на 0,8 см $(19,0 \%)$, а в среднем за два года на 1,0 см $(21,7$ $\%)$.

Из данных таблицы 6 видно, что в 2011 г. в контрольных вариантах наблюдается очень сильное варьирование укореняемости. Данный показатель колебался от $13,3 \%$ на сорте Кобер 5ББ, до 70,0 \% на сорте Гравесак.

Таблица 6 - Укореняемость черенков подвойных филлоксероустойчивых сортов винограда под влиянием обработки их гетероауксином

\begin{tabular}{|c|c|c|c|c|}
\hline \multirow{2}{*}{ Сорт } & \multirow{2}{*}{ Вариант } & \multicolumn{3}{|c|}{$\begin{array}{c}\text { Укореняемость, } \\
\%\end{array}$} \\
\hline & & $2011 г$. & 2012 г. & $\begin{array}{c}\text { среднее за } \\
2011-2012 \text { гг. }\end{array}$ \\
\hline \multirow[t]{2}{*}{ Кобер 5ББ } & контроль & 13,3 & 27,5 & 20,4 \\
\hline & гетероауксин & 73,3 & 62,5 & 67,9 \\
\hline \multirow[t]{2}{*}{$101-14$} & контроль & 46,7 & 25,0 & 35,8 \\
\hline & гетероауксин & 83,3 & 65,0 & 74,2 \\
\hline \multirow[t]{2}{*}{$\mathrm{CO}-4$} & контроль & 20,0 & 12,5 & 16,2 \\
\hline & гетероауксин & 43,3 & 47,5 & 45,4 \\
\hline \multirow{2}{*}{ Гравесак } & контроль & 70,0 & 32,5 & 51,2 \\
\hline & гетероауксин & 96,7 & 85,0 & 90,8 \\
\hline \multirow[t]{2}{*}{ РСБ } & контроль & 22,6 & 32,5 & 27,6 \\
\hline & гетероауксин & 17,3 & 72,5 & 44,9 \\
\hline \multirow[t]{2}{*}{$5 Ц$} & контроль & 63,3 & 7,5 & 35,6 \\
\hline & гетероауксин & 80 & 32,5 & 56,2 \\
\hline \multirow[t]{2}{*}{ Среднее по опыту } & контроль & 39,3 & 22,9 & 31,1 \\
\hline & гетероауксин & 65,6 & 60,8 & 63,2 \\
\hline \multicolumn{2}{|c|}{$\mathrm{HCP}_{01}$ (сорта -фактор А) } & 5,60 & 7,07 & 4,23 \\
\hline \multicolumn{2}{|c|}{$\mathrm{HCP}_{01}(\Phi \mathrm{AB} \mathrm{-} \mathrm{фактор} \mathrm{Б)}$} & 3,24 & 4,08 & 2,44 \\
\hline \multicolumn{2}{|c|}{$\mathrm{HCP}_{01}$ (взаимодействие факторов - АБ) } & 7,92 & 10,0 & 5,98 \\
\hline
\end{tabular}


Сорта Кобер 5ББ, СО-4 и РСБ с укореняемостью 13,3 - 22,6\% вошли в группу со слабой ризогенной активностью, 101-14 (46,7\%) - средней, а $5 Ц$ и Гравесак $(63,3$ и 70,0\%) - высокой. Разница между укореняемостью во всех трех группах достоверна.

Достоверна, также оказалась разница по укореняемости между сортами Кобер 5ББ с одной стороны и СО-4 и РСБ - с другой, входящими в одну группу, а также 5С и Гравесак, составившими другую группу.

В 2012 г. наблюдалось снижение укореняемости по сравнению с предыдущим годом. Она колебалась от 7,5\% на сорте 5Ц, до $32,5 \%$ на сортах Гравесак и РСБ. Сорта Кобер 5ББ, 101-14, СО-4 и 5Ц составили группу сортов с низкой ризогенной активностью, а сорта Гравесак и РСБ с средней.

Сравнение укореняемости по годам показало, что на сортах Кобер 5ББ и РСБ в 2011 г. данный показатель был на 14,2 и 9,9\% ниже, чем в 2012 г. В остальных четырех случаях более высокая укореняемость наблюдалась в 2011 г. При этом на сортах 101-14, Гравесак и 5 Ц разница по годам была очень значительной и составляла соответственно 21,7; 37,5 и 55,8\%. Таким образом, эти сорта, входящие в 2011 г., в группы со средней, высокой и высокой укореняемости, в 2012 г. оказались в группах с низкой, средней и низкой укореняемостью.

В среднем по опыту укореняемость в 2011 г. составила 39,3\%, а в 2012 г. - 22,9\%, то есть на 16,4\% меньше.

В среднем за два года укореняемость колебалась от $16,2 \%$ на сорте CO-4, до 51,2\% на сорте Гравесак, то есть от низкой до высокой. Низкой также оказалась укореняемость на сортах Кобер 5ББ и РСБ, составившая соответственно 20,4 и 27,6\%. Сорта 101-14 и 5 Ц с фактически одинаковой приживаемостью 35,8 и $35,6 \%$ вошли в группу со средней приживаемостью. 
Выявленные нами закономерности по потенциальной ризогенной активности черенков подвойных сортов отличаются от данных полученных Л.М. Малтабаром и Н.И. Мельником [12] при укоренении черенков этих же сортов в условиях Темрюкского района края. В исследованиях данных авторов самой высокой ризогенной активностью выделялись черенки сорта РСБ, высокой - 101-14 и Кобера 5 ББ, средней Гравесак, ниже средней - 5С и низкой - CO-4. Как видно из приведенных данных только сорт СО-4 подтвердил репутацию слабо укореняющегося сорта.

Применение гетероауксина на всех сортах в оба года проведения исследований оказало сильное влияние на увеличение укореняемости. Исключение составил лишь сорт РСБ в 2011 г., на котором укореняемость в опытном варианте снизилась по сравнению с контролем на 5,3\%, хотя разница оказалась недостоверной.

В 2011 г. укореняемость в опытных вариантах, за исключением сорта РСБ, составила 43,3 - 96,7\%, превысив контрольный вариант на 16,7 $60,0 \%$ при $\mathrm{HCP}_{01}=3,24 \%$, а в 2012 г. - 32,5 - 85,0\%, с превышением контрольного варианта на 25,0 - 52,5\%, при $\mathrm{HCP}_{01}=4,08 \%$.

В 2011 г. наименьшее превышение показателя (16,7\%) отмечено на сорте 5Ц, а наибольшее $(60,0 \%)$ на сорте Кобер 5ББ. На остальных трех сортах оно колебалось в пределах $23,3-36,6 \%$.

В 2012 г., также как и в предыдущем, наименьшее увеличение укореняемости, хотя и на большую величину $(25,0 \%)$ отмечено на сорте $5 Ц$, а наибольшее $(52,5 \%)$ на сорте Гравесак. На остальных четырех сортах величина прибавки была примерно одинаковой и находилась в пределах 35,0 - 40,0 \%. Применение гетероауксина значительно усилило регенерационную способность черенков испытываемых сортов, что дало возможность перенести их в более высокие группы ризогенной активности. 
В 2011 г. только сорт CO-4 переместился из группы с низкой, в группу с высокой ризогенной активностью. Остальные четыре сорта Кобер 5ББ, 101-14, Гравесак и 5Ц, у которых укореняемость достигла 73,3 - 96,7\% переместились в группу с очень высокой ризогенной активностью.

В 2012 г. сорта СО-4 и 5Ц из группы с низкой ризогенной активностью перешли в группу со средней; сорта Кобер 5ББ и 101-14, также из группы с низкой, в группу с высокой и сорта Гравесак и РСБ - в группу с очень высокой ризогенной активностью.

В среднем за два года в опытном варианте в группе со средней ризогенной активностью оказались сорта СО-4 и РСБ $(45,4$ и 44,9 \%); с высокой - Кобер 5ББ и 5Ц $(67,9$ и 56,2\%) и очень высокой - 101-14 и Гравесак $(74,2$ и 90,8\%).

Сравнение превышения укореняемости в опытном варианте, по сравнению с контрольным, за два года показывает, что за исключением сорта Кобер 5ББ, наибольшее превышение наблюдалось в 2012 г., где в большинстве случаев в контрольном варианте укореняемость была ниже, чем в 2011 г. Лишь на сорте Кобер 5ББ, где в контрольном варианте более низкая укореняемость получена в 2011 г., наибольшее превышение также получено в этом году. Следует отметить, что из всех сортов за два года исследований - это была набольшая прибавка.

В среднем по опыту увеличения укореняемости под влиянием обработки черенков гетероуксином в 2011 г. составила 26,3 \%, а в 2012 $37,9 \%$, то есть было на $11,6 \%$ больше.

В среднем за 2 года укореняемость в опытном варианте увеличилась до 44,9 \% (РСБ) - 90,8 \% (Гравесак). Превышение по сравнению с контролем колебалось от 17,3 \% на сорте РСБ до 46,8 \% на сорте Кобер 5ББ. На сортах 101-14, Гравесак и 5Ц превышение было примерно одинаковым и находилось в пределах 37,9 - 39,6 \%. В среднем по опыту 
оно составило $32,1 \%$, что является очень значительной величиной. Разница во всех случаях была достоверной.

Однако в исследованиях Л.М. Малтабара и Н.И. Мельника [12] с черенками этих же сортов гетероауксин практически не оказал заметного влияния на их приживаемость в школке открытого грунта. Так гетероауксин практически не оказал никакого влияния на приживаемость черенков сорта Гравесак, у сортов Кобер 5 ББ, 5Ц, Феркаль и РСБ приживаемость увеличилась только на 2,5-3,9 \%, что, скорее всего, было в пределах ошибки опыта. Максимальное превышение укореняемости, составившее 5,7 и 6,1 \%, наблюдалось только на сортах 101-14 и СО-4.

Что касается такого хозяйственно-важного показателя корнеобразовательной способности черенков, как выход черенков с тремя корнями и более, то в контрольных вариантах он получился сравнительно низким, особенно в 2012 г. (таблица 7).

Таблица 7 - Выход укорененных черенков подвойных филлоксероустойчивых сортов винограда с 3-мя корнями и более под влиянием обработки их гетероауксином

\begin{tabular}{|c|c|c|c|c|}
\hline \multirow[b]{2}{*}{ Сорт } & \multirow[b]{2}{*}{ Вариант } & \multicolumn{3}{|c|}{ Черенков с 3-мя корнями и более, \% } \\
\hline & & $2011 г$. & 2012 г. & $\begin{array}{c}\text { среднее за 2011- } \\
2012 \text { гг. }\end{array}$ \\
\hline \multirow[t]{2}{*}{ Кобер 5ББ } & контроль & 0 & 0 & 0 \\
\hline & гетероауксин & 54,7 & 20,0 & 37,4 \\
\hline \multirow[t]{2}{*}{$101-14$} & контроль & 21,7 & 10,0 & 15,8 \\
\hline & гетероауксин & 72,2 & 32,5 & 52,4 \\
\hline \multirow[t]{2}{*}{$\mathrm{CO}-4$} & контроль & 0 & 2,5 & 1,2 \\
\hline & гетероауксин & 15,0 & 12,5 & 13,8 \\
\hline \multirow[t]{2}{*}{ Гравесак } & контроль & 42,8 & 7,5 & 25,2 \\
\hline & гетероауксин & 86,3 & 65,0 & 75,6 \\
\hline \multirow[t]{2}{*}{ РСБ } & контроль & 16,7 & 5,0 & 10,8 \\
\hline & гетероауксин & 0 & 22,5 & 11,2 \\
\hline \multirow[t]{2}{*}{5 Ц } & контроль & 33,3 & 0 & 16,6 \\
\hline & гетероауксин & 46,7 & 2,5 & 24,6 \\
\hline \multirow[t]{2}{*}{ Среднее по опыту } & контроль & 13,5 & 4,2 & 8,8 \\
\hline & гетероауксин & 38,0 & 25,8 & 31,9 \\
\hline \multicolumn{2}{|c|}{$\mathrm{HCP}_{01}$ (сорта -фактор А) } & 10,74 & 7,76 & 6,59 \\
\hline \multicolumn{2}{|l|}{$\mathrm{HCP}_{01}($ ФАВ - фактор Б) } & 6,20 & 4,48 & 3,81 \\
\hline \multicolumn{2}{|c|}{$\mathrm{HCP}_{01}$ (взаимодействие факторов - АБ) } & 15,19 & 10,98 & 9,32 \\
\hline
\end{tabular}


В 2011 г. и 2012 гг., на сорте Кобер 5ББ, а также в 2011 г. на сорте CO-4 и 2012 г. на сорте 5Ц вообще не было черенков с тремя и более корнями, то есть, все укоренившиеся черенки имели одному-два корня.

В 2011 г. количество черенков, имеющих не менее трех корней колебалось по вариантам опыта от 16,7 \% на сорте РСБ до 42,8 \% на сорте Гравесак, а в 2012 г.- от 2,5 \% на сорте СО-4 до 10,0 \% на сорте 101-14.

В 2011 г. разница между сортами 101-14 и РСБ с одной стороны, и Гравесак и 5Ц с другой, а также между сортами Гравесак и 5Ц была достоверной. В 2012 г. этот показатель между изучаемымисортами с укоренившимися черенками оказался недостоверным, то есть находился в пределах ошибки опыта.

Как уже упоминалось ранее в 2011 г. в контрольном варианте на всех сортах, за исключением СО-4, выход черенков с тремя корнями и более был выше, чем в 2012 г. В среднем по опыту в 2011 г. он составил 13,5 \%, а в 2012 г.-4,2\%.

В среднем за два года данный показатель колебался от 1,2 \% на сорте CO-4, до 25,2 \% на сорте Гравесак. У сорта Кобер 5 ББ, как уже упоминалось выше, в оба года не выявлено черенков имеющих не менее трех корней.

Применение гетероауксина в большинстве случаев оказало значительное положительное влияние на анализируемый показатель. Лишь на сорте РСБ в 2011 г. в опытном варианте вообще не оказалось черенков с тремя и более корнями, тогда как в контрольном варианте их было 16,7 \%. На сорте 5Ц в 2012 г. в опытном варианте черенков не менее, чем с тремя корнями было всего 2,5\%.

В остальных случаях выход черенков с тремя корнями и более в 2011 г. колебался от 15,0 \% на сорте СО-4, до 86,3 \% на сорте Гравесак, а в 2012 г. от 12,5 до $65,0 \%$ на тех же сортах. 
В оба года проведения исследований наименьший выход черенков с тремя корнями и более был получен на сорте CO-4, соответственно 15,0 и $12,5 \%$, а наибольший на сорте Гравесак, 86,3 и 65,0 \%. Достаточно высокое значение показателя отмечено также в 2011 г. на сорте 101-14. На остальных сортах в 2011 г. показатель колебался в пределах 46,3 - 54,7 \%, а в 2012 г. - $20-32,5 \%$. Так же, как и в контрольном варианте, средняя по опыту величина выхода черенков не менее чем с тремя корнями в 2011 г. была выше, чем в 2012 г. и составила $38,0 \%$ против $25,8 \%$.

Наименьшее превышение выхода черенков с тремя корнями и более в опытном варианте в 2011 г., выявлено на сортах 5Ц и СО-4. Оно составило соответственно 13,4 \% и 15,0 \%. На сортах Гравесак, 101-14 и Кобер 5ББ превышение было значительно большим и находилось в пределах 43,5 - 54,7\%.

В 2012 г., также как и в предыдущем, максимальное увеличение анализируемого показателя $(57,5 \%)$ произошло на сорте Гравесак, а минимальное $(10,0$ \%) на сорте СО-4. На сортах РСБ, Кобер 5ББ и 101-14 оно колебалось в пределах 17,5 - 22,5\%.

Разница по величине показателя между контрольным и опытным вариантами в оба года на всех сортах достоверно, за исключением сорта 5Ц в 2012 г.

Среднее превышение показателя по опыту в варианте с гетероуксином составило в 2011 г. $-24,5 \%$, а в 2012 г. $-21,6 \%$.

В среднем за два года только на сорте РСБ в варианте с гетероуксином не отмечено увеличение показателя. На остальных пяти сортах наблюдалась достоверная прибавка. Наименьшей она была на сортах 5Ц и СО-4 (8,0 \% и 12,6 \%). На сортах Кобер 5ББ и 101-14 она была примерно одинаковой и составила $37,4 \%$ и $36,6 \%$. Максимальное значение показателя $(50,4 \%)$ отмечено на сорте Гравесак. В среднем по опыту 
увеличение показателя под влиянием гетероауксина составило 23,1\%, разница во всех случаях достоверна.

Как уже упоминалось ранее, выход черенков с тремя корнями и более, зависит, как от укореняемости, так и от среднего количества корней, образовавшихся на базальных частях черенков.

Следует отметить, что в контрольном варианте на всех сортах в оба года проведения исследований, количество образовавшихся корней было меньше нижнего допустимого предела - 3 шт. (таблица 8).

Таблица 8 - Количество корней, образовавшихся на базальных концах черенков подвойных филлоксероустойчивых сортов винограда под влиянием обработки их гетероауксином

\begin{tabular}{|c|c|c|c|c|}
\hline \multirow[b]{2}{*}{ Сорт } & \multirow[b]{2}{*}{ Вариант } & \multicolumn{3}{|c|}{ Корней на черенок, шт. } \\
\hline & & 2011 г. & 2012 г. & $\begin{array}{c}\text { среднее за } \\
2011-2012 \\
\text { гг. }\end{array}$ \\
\hline \multirow[t]{2}{*}{ Кобер 5ББ } & контроль & 1,3 & 1,3 & 1,3 \\
\hline & гетероауксин & 3,0 & 2,4 & 2,7 \\
\hline \multirow[t]{2}{*}{$101-14$} & контроль & 1,6 & 1,3 & 1,4 \\
\hline & гетероауксин & 4,3 & 2,8 & 3,6 \\
\hline \multirow[t]{2}{*}{$\mathrm{CO}-4$} & контроль & 1,0 & 1,8 & 1,4 \\
\hline & гетероауксин & 1,7 & 2,1 & 2,2 \\
\hline \multirow[t]{2}{*}{ Гравесак } & контроль & 2,8 & 1,7 & 2,2 \\
\hline & гетероауксин & 5,1 & 5,4 & 5,2 \\
\hline \multirow[t]{2}{*}{ РСБ } & контроль & 1,5 & 1,6 & 1,6 \\
\hline & гетероауксин & 1,0 & 2,5 & 1,8 \\
\hline \multirow[t]{2}{*}{5 Ц } & контроль & 2,9 & 1,0 & 2,0 \\
\hline & гетероауксин & 2,7 & 1,5 & 2,1 \\
\hline \multirow[t]{2}{*}{ Среднее по опыту } & контроль & 1,8 & 1,5 & 1,6 \\
\hline & гетероауксин & 3,0 & 2,8 & 2,9 \\
\hline \multicolumn{2}{|l|}{$\mathrm{HCP}_{01}($ сорта -фактор A) } & 0,30 & 0,47 & 0,30 \\
\hline \multicolumn{2}{|l|}{$\mathrm{HCP}_{01}($ ФАВ - фактор Б) } & 0,17 & 0,27 & 0,17 \\
\hline \multicolumn{2}{|c|}{$\mathrm{HCP}_{01}$ (взаимодействие факторов - АБ) } & 0,42 & 0,66 & 0,42 \\
\hline
\end{tabular}

Однако данные дисперсионного анализа показывают, что между ними есть существенная разница. Так в 2011 г., максимальное количество корней (2,8 и 2,9 шт.) образовалось на сортах Гравесак и 5Ц. Достоверно 
меньше корней (1,3 и 1,6 шт.) отмечено на сортах Кобер 5ББ, 101-14 и РСБ. Минимальное количество корней наблюдалось на сорте СО-4.

В 2012 г. максимальное количество корней, как и в предыдущем году, отмечено на сорте Гравесак (1,7 шт.), а также на сортах СО-4 и РСБ. Наименьшее значение показателя (1,0 шт.) наблюдалось на сорте 5Ц. Сорта Кобер 5ББ и 101-14, так как и в предыдущем году занимали промежуточное положение.

Так же, как и в рассмотренных выше двух других показателях корнеобразовательной способности черенков, численные значения среднего количества корней в 2011 г. были несколько больше, чем в 2012 г. В среднем по опыту разница составила 0,3 шт. Уменьшение по сравнению с 2011 г. составило $16,7 \%$.

Применение гетероауксина оказало значительное стимулирующее влияние на образование корней. Однако степень стимулирования этого процесса зависела от сортовых особенностей и условий года. Исключения составили только сорта РСБ и 5Ц в 2011 г., где в вариантах с гетероауксином количество корней достоверно уменьшилось.

В 2011 г., количество корней в опытном варианте увеличилось на 0,7 - 2,7 шт., или 70,0 \% - 168,8 \%, а в 2012 г. на 0,3 - 3,7 шт., или 16,7 \% $217,6 \%$. В оба года максимальное увеличение количества корней наблюдалось на сортах Гравесак (2,3 и 3,7 шт., или 82,1 \% и 217,6 \%), 10114 (2,7 и 1,5 шт., или 168,8 \% и 115,4 \%), Кобер 5ББ (1,7 и 1,1 шт., или $130,8 \%$ и 84,6 \%). В среднем за два года увеличение показателя на этих сортах составило соответственно 3,0; 2,2 и 1,4 шт., или 136,4; 157,1 и 107,7 $\%$.

Наименьшее увеличение анализируемого показателя в оба года наблюдалось на сорте CO-4, а в 2012 г. на сортах 5Ц и РСБ.

В среднем за два года на сортах СО-4 и РСБ превышение количества корней в опытном варианте оказалось достоверным и составило 
соответственно 0,8 и 0,2 шт., при $\mathrm{HCP}_{01}=0,17$ шт. На сорте 5Ц показатели в обоих вариантах оказались примерно одинаковыми.

Что касается условий года, то здесь каких-либо закономерностей не выявлено. Так у сортов Кобер 5ББ, 101-14 и 5Ц большее количество корней на черенках опытных вариантов выявлены в 2011 г., а у сортов СО4, Гравесак и РСБ в 2012 г. В среднем по опыту количество корней в варианте с гетероауксином в 2011 г. оказалось на 0,2 шт., или на 6,7\% больше, чем в 2012 г.

Проведенный нами корреляционный анализ на предмет установления наличия взаимосвязей и взаимозависимостей между показателями, характеризующими регенерационную способность черенков, показал, что между количеством черенков с распустившимися глазками и остальными показателями корреляции практически отсутствуют (таблица 9).

Лишь с длиной побегов в контрольном варианте выявлены положительные в 2011 г. выявлена средняя недостоверная положительная корреляция $(\mathrm{r}=0,37)$, а в 2012 г. - средняя достоверная $(\mathrm{r}=$ 0,58).корреляции между количеством черенков с распустившимися глазками и длиной побегов. Можно предположить, что чем здоровее были почки в зимующих глазках, тем распустилось больше глазков, и тем больше оказалась длина развившихся побегов.

Однако, в вариантах с гетероауксином данная корреляция уже не проявлялась. Это может быть следствием ингибирования распускания глазков под действием гетероауксина в начальный период опыта, о чем свидетельствуют данные многих исследователей, подтвержденные и нашими многочисленными опытами [15,17,19,20,21,28,38].

Что касается взаимосвязей между количеством черенков с распустившимися глазками и показателями корнеобразовательной 
способности черенков в контрольном варианте в оба года проведения исследований, а в опытном - в 2011 г., они не выявлены.

Таблица 9 - Наличие, степень и направленность корреляционных зависимостей между показателями регенерационных процессов у трехглазковых черенков подвойных филлоксероустойчивых сортов винограда

\begin{tabular}{|c|c|c|c|c|c|}
\hline \multirow[b]{2}{*}{ Показатели } & \multicolumn{5}{|c|}{ Коэффициент корреляции Спирмана (r) } \\
\hline & $\begin{array}{c}\text { Годы } \\
\text { исследо- } \\
\text { ваний }\end{array}$ & $\begin{array}{c}\text { Длина } \\
\text { побегов, } \\
\text { см }\end{array}$ & $\begin{array}{c}\text { Укоре- } \\
\text { няемость, } \\
\%\end{array}$ & $\begin{array}{c}\text { Черенков с } \\
\text { 3-мя } \\
\text { корнями и } \\
\text { более, } \\
\%\end{array}$ & $\begin{array}{c}\text { Корней на } \\
\text { черенок, } \\
\text { шт. }\end{array}$ \\
\hline \multicolumn{6}{|c|}{ Контроль } \\
\hline \multirow{2}{*}{$\begin{array}{l}\text { Черенков с } \\
\text { распустившимися } \\
\text { глазками, \% }\end{array}$} & 2011 & 0,37 & $-0,095$ & $-0,13$ & $-0,04$ \\
\hline & 2012 & $0,58 *$ & $-0,27$ & 0,17 & $0,03-$ \\
\hline \multirow[t]{2}{*}{ Длина побегов,см } & 2011 & - & 0,11 & 0,10 & 0,14 \\
\hline & 2012 & - & $0,59 *$ & $0,71 *$ & $0,73 *$ \\
\hline \multirow[t]{2}{*}{ Укореняемость,\% } & 2011 & - & - & $0,84^{*}$ & $0,80 *$ \\
\hline & 2012 & - & - & 0,37 & 0,43 \\
\hline \multirow{2}{*}{$\begin{array}{l}\text { Черенков с 3-мя } \\
\text { корнями и более,\% }\end{array}$} & 2011 & - & - & - & $0,79 *$ \\
\hline & 2012 & - & - & - & $0,80^{*}$ \\
\hline \multicolumn{6}{|c|}{ Радикс плюс } \\
\hline \multirow{2}{*}{$\begin{array}{l}\text { Черенков с } \\
\text { распустившимися } \\
\text { глазками, \% }\end{array}$} & 2011 & 0,04 & $-0,19$ & $-0,05$ & $-0,1$ \\
\hline & 2012 & 0,11 & $0,47^{*}$ & 0,39 & 0,38 \\
\hline \multirow[t]{2}{*}{ Длина побегов,см } & 2011 & - & $0,81^{*}$ & $0,82 *$ & $0,80 *$ \\
\hline & 2012 & - & $0,77 *$ & $0,72 *$ & $0,80 *$ \\
\hline \multirow[t]{2}{*}{ Укореняемость,\% } & 2011 & - & - & $0,87 *$ & $0,91 *$ \\
\hline & 2012 & - & - & $0,85^{*}$ & $0,78^{*}$ \\
\hline \multirow{2}{*}{$\begin{array}{l}\text { Черенков с 3-мя } \\
\text { корнями и более,\% }\end{array}$} & 2011 & & & & $0,97 *$ \\
\hline & 2012 & & & & $0,87 *$ \\
\hline
\end{tabular}

Только в 2012 г. наблюдалась слабая отрицательная корреляция с укореняемостью $(\mathrm{r}=-0,27)$. Однако в 2012 г. в опытном варианте выявлена достоверная средняя положительная корреляция с укореняемостью $(\mathrm{r}=0,47)$, и недостоверная средняя - с выходом черенков с тремя и более корнями и средним количеством корней $(\mathrm{r}=0,39$ и $\mathrm{r}=$ 
0,38). Таким образом, при обработке черенков гетероауксином в 2012 г. увеличение количества черенков с распустившимися глазками сопровождалось увеличением укореняемости, количества корней на черенках и выхода черенков с тремя корнями и более.

Между длиной побегов в контрольном варианте в 2011 г. и показателями корнеобразовательной способности черенков корреляционные связи отсутствовали, однако, в 2012 г. в контрольном варианте и в оба года в опытном - присутствовали. В восьми случаях из девяти корреляция была достоверной, положительной и сильной $(\mathrm{r}=0,71-$ 0,82). Лишь в 2011 г. с укореняемостью в контрольном варианте она оказалась средней $(\mathrm{r}=0,59)$.

О существовании положительной зависимости между длиной побегов и развитием корневой системы, как уже указывалось нами ранее, упоминают и другие исследователи [1,2,5,7,11,14,42]. В результате проведенного анализа в опытном и контрольном вариантах выявлена также сильная, положительная зависимость между всеми тремя показателями корнеобразовательной способности черенков. Лишь в контрольном варианте в 2011 г. корреляция между укореняемостью и двумя другими показателями оказалась недостоверной средней. Это можно объяснить тем, что укореняемость в большей степени зависит от гормональной активности глазков, а количество корней, образовавшихся на черенках - от запаса питательных веществ черенка [30,31,33,36,37,40,44,45].

Для того чтобы более детально разобраться с причинами различной регенерационной способности черенков у разных сортов, нами была рассчитана доля влияния изучаемых факторов, на показатели их регенерационной способности (таблица 10).

Как видно из данных таблицы, в оба года проведения исследований применение гетероауксина не оказало никакого влияния на количество черенков с распустившимися глазками. Данный показатель зависел от 
сортовых особенностей $(27,6 \%$ и 37,6 \%), взаимодействия сорта и ФАВ $(21,1 \%$ и 39,6 \%) и привходящих (т.е. случайных) факторов (51,2 \% и 22,7 $\%)$.

Таблица 10 - Доля влияния изучаемых факторов на показатели регенерационных процессов

черенков подвойных филлоксероустойчивых сортов винограда под влиянием обработки их гетероауксином (\%)

\begin{tabular}{|c|c|c|c|c|c|}
\hline Фактор & $\begin{array}{c}\text { Черенков с } \\
\text { распустившимися } \\
\text { глазками, } \\
\%\end{array}$ & $\begin{array}{c}\text { Длина } \\
\text { побегов, } \\
\text { см }\end{array}$ & $\begin{array}{c}\text { Укореняемость, } \\
\%\end{array}$ & $\begin{array}{c}\text { Черенков } \\
\text { с 3-я } \\
\text { корнями } \\
\text { и более, } \\
\%\end{array}$ & $\begin{array}{c}\text { Корней } \\
\text { на } \\
\text { черенок, } \\
\text { шт. }\end{array}$ \\
\hline \multicolumn{6}{|c|}{2011 г. } \\
\hline $\begin{array}{l}\text { Сорта } \text { (фактор } \\
\text { А) }\end{array}$ & 27,6 & 57,2 & 63,4 & 50,1 & 55,0 \\
\hline ФАВ (фактор Б) & 0,1 & 5,1 & 21,6 & 21,2 & 18,9 \\
\hline $\begin{array}{l}\text { Взаимодействие } \\
\text { факторов (АБ) }\end{array}$ & 21,1 & 27,4 & 12,2 & 19,0 & 22,2 \\
\hline Остаточная & 51,2 & 10,3 & 2,8 & 9,7 & 3,9 \\
\hline \multicolumn{6}{|c|}{2012 г. } \\
\hline $\begin{array}{l}\text { Сорта (фактор } \\
\text { А) }\end{array}$ & 37,6 & 45,2 & 28,7 & 35,1 & 36,2 \\
\hline ФАВ (фактор Б) & 0,1 & 9,7 & 61,6 & 32,4 & 28,4 \\
\hline $\begin{array}{l}\text { Взаимодействие } \\
\text { факторов (АБ) }\end{array}$ & 39,6 & 25,7 & 3,6 & 20,8 & 24,1 \\
\hline Остаточная & 22,7 & 19,4 & 6,1 & 11,7 & 11,3 \\
\hline \multicolumn{6}{|c|}{ Среднее за 2011-2012 гг. } \\
\hline $\begin{array}{l}\text { Сорта (фактор } \\
\text { A) }\end{array}$ & 29,2 & 49,6 & 36,6 & 45,4 & 43,4 \\
\hline ФАВ (фактор Б) & 0,1 & 8,7 & 54,3 & 30,7 & 29,3 \\
\hline $\begin{array}{l}\text { Взаимодействие } \\
\text { факторов (АБ) }\end{array}$ & 37,8 & 31,0 & 6,4 & 17,4 & 22 \\
\hline Остаточная & 33,0 & 10,7 & 2,7 & 6,5 & 5,3 \\
\hline
\end{tabular}

На длину побегов применение гетероауксина оказало лишь небольшое влияние. Доля влияния этого фактора по годам составила 5,1 и 9,7 \%. Однако основное влияние на длину побегов оказали сортовые особенности, особенно в 2011 г., где доля влияния составила 57,2 \% при 45,2 \% в 2012 г. На втором месте по силе влияния находилось 
взаимодействие факторов $(27,4$ и $25,7 \%)$ и затем - случайные факторы $(10,3 \%$ и $19,4 \%)$.

Следует отметить, что доля влияния факторов в значительной степени зависела и от условий года, что наглядно проявилось на показателях корнеобразовательной способности черенков.

Так, укореняемость в 2011 г. на 63,4 \% зависела от сортовых особенностей, на $21,6 \%$ от ФАВ и на $12,2 \%$ от взаимодействия факторов. Влияние случайных факторов было мизерным и составляло всего лишь 2,8 \%. В 2012 г. доля влияния сортовых особенностей уменьшилась до 28,7 \%, но зато резко возросло влияние ФАВ (гетероауксина), которое составило $61,6 \%$. Влияние взаимодействия факторов и случайных факторов было незначительным, всего лишь (3,6 \% и 6,1 \%).

В 2011 г. примерно такая же зависимость, как с укореняемостью, наблюдалась и на двух других показателях корнеобразовательной способности - количестве черенков с тремя корнями и более, и среднем количестве корней, развившихся на один черенок. Основное влияние на эти показатели $(50,1 \%$ и 55,0 \%) оказали сортовые особенности. Влияние ФАВ и взаимодействия факторов было примерно одинаковым и составило 21,2 \% и 19,0 \% на первом показателе и $18,9 \%$ и 22,2 \% на втором. Меньше всего на анализируемые показатели оказали влияние случайные факторы, соответственно 9,7 \% и 3,9\%.

В 2011 г. остальные два показателя корнеобразовательной способности черенков - выход черенков с тремя корнями и более и среднее количество корней, приходящееся на один черенок, так же, как и укореняемость, определились в первую очередь сортовыми особенностями (доля влияния 50,1 \% и 55,0 \%). Влияние ФАВ (гетероауксина) и взаимодействия факторов было примерно одинаковым и составляло 21,2 \% и 19,0 \% на первом показателе и $18,9 \%$ и 22,2 \% - на втором. Доля 
случайных факторов составляла соответственно 9,7 \% и 3,9 \%, т.е. была минимальной.

В 2012 г. на выход черенков не менее чем с тремя корнями и количество корней оказали также большое влияние сортовые особенности. Однако их влияние было несколько меньше, чем в предыдущем году. Если в 2011 г. доля влияния этого фактора составляла 50,1\% и 55,0 \%, то в 2012 г. - 35,1\% и 36,2\%. Влияние ФАВ на выход черенков с тремя корнями и более лишь немного уступало сортовым особенностям и равнялось $32,4 \%$, а взаимодействие факторов составляло примерно пятую часть (20,8\%).

Доля влияния ФАВ на количество корней была несколько меньшей, чем на предыдущий показатель $(28,4 \%)$, но зато увеличилось влияние взаимодействия факторов, составившее $24,1 \%$.

Влияние доли случайных факторов на оба показателя оказалось примерно одинаковым и составило $11,7 \%$ и $11,3 \%$.

Если рассмотреть все изучаемые показатели, то наибольшее влияние случайные факторы оказали на количество черенков с распустившимися глазками $(51,2 \%$ и 22,7\%), длину побегов (10,3\% и 19,4\%) и выход черенков с тремя корнями и более, а наименьшее на укореняемость $(2,8 \%$ и $6,1 \%)$.

На основании проведенных исследований можно сделать выводы, что потенциальная ризогенная активность черенков зависит не только от сортовых особенностей, но и от их физиологического состояния. Так низкая ризогенная активность в оба года наблюдалась у сортов Кобер 5 ББ и СО-4, низкая и средняя - 101-14 и РСБ, слабая и высокая - 5Ц и средняя и высокая - Гравесак.

Обработка базальных концов черенков 0,01\%-ным раствором гетероауксина в значительной степени способствовала активизации в них регенерационных процессов, что выразилось в: существенном увеличении количества черенков с распустившимся глазком на сорте 101-14; 
увеличении длины побегов на сортах 5Ц, 101-14 и Гравесак на 23,1-157,6 $\%$; увеличении укореняемости черенков от 16,7 \% на сорте 5 Ц до 60,0 \% на сорте Кобер 5ББ, а количества черенков имеющих не менее трех корней, соответственно, от 13,0 \% до 54,7 \%; увеличении числа корней на базальных концах черенков от 0,7 шт. на сорте CO-4, до 2,7 шт. на сорте 101-14 или в 1,7-2,7 раза.

Максимальная длина побегов в опытном варианте наблюдалась на тех сортах, где в контрольном варианте наблюдалась наибольшая ризогенная активность.

Лишь на сорте РСБ применение гетероауксина не привело к положительным результатам, что можно объяснить только его биологическими особенностями.

\section{Библиографический список}

1. Алиев Н.А. Широкорядные высокоштамбовые виноградники. - Махачкала: Даг. кн. изд-во, 1980. - 109 с.

2. Гаджиев 3.Ш. Широкорядный способ возделывания винограда / З.Ш. Гаджиев // Садоводство, виноградарство и виноделие Молдавии. - 1979. - № 12. - с. 34-36.

3. Громаковский И.К. По пути интенсификации виноградного питомниководства / И.К. Громаковский // Интенсификация производства винограда - важный фактор реализации продовольственной программы: список тезисов докладов Республиканской конференции по виноградарству (7.09.1984 г.). - Кишинев, 1984. - С. 18-20.

4. Гудумак Ф.А. Влияние ретардантов на рост побегов, выход и регенерационную активность черенков у сорта подвоя винограда Берландиери $\times$ Рипариа СО -4 / Ф.А. Гудумак // Состояние и перспективы развития виноградарства: тез. докл. Респ. науч.-практ. конф. (19-21 сентября 1990 г). - Кишинев, 1990.- С. 58-59.

5. Дубинко В.К. Интенсивные способы выращивания винограда / В.К. Дубинко, В.Ф. Карзов. - Киев: Урожай, 1981. - 96 с.

6. Казалиев М.М. Влияние привоя и подвоя на качество прививок и выход саженцев / М.М. Казалиев, С.Д. Раджабов, Я.М. Пейсотов // Виноград и вино России. - 1997. - №3. - С. 12 14.

7. Ломкаци С.И. Корневая система винограда в связи с нагрузкой // Садоводство, виноградарство и виноделие Молдавии. - 1963. - №2. - С. 32-33.

8. Малтабар Л.М. Виноградный питомник (теория и практика) / Л.М. Малтабар, Д.М. Козаченко. - Краснодар, 2009. - 290 с.

9. Малтабар Л.М. Ризогенная активность черенков новых сортов винограда при окоренении их на воде и в брикетах из гравилена / Л.М. Малтабар, П.П. Радчевский, Н.Д. Магомедов // Виноград и вино России. - 1996. - №5. - С. 11-13.

10. Мартынова И.Н. Адаптация подвойных сортов винограда к условиям Нижнего Придонья. / И.Н. Мартынова, Т.Б. Шатилова, Н.О. Арестова // Виноград и вино России. - 1997. - №3. - C. 9-11.

11. Мелконян А.С. Влияние различных норм нагрузки на мощность молодых кустов винограда: автореф. дис. ... канд. с.-х. наук. - Одесса, 1958. - 20 с. 
12. Мельник Н.И. Продуктивность и эффективность подвойных сортов винограда и привойно-подвойных комбинаций в Таманской подзоне Анапо-Таманской сельскохозяйственной зоны: автореф. дис. ... канд. с.-х. наук. - Краснодар, $2007-25$ с.

13. Николенко В.Г. Выход привитых саженцев по различным комбинациям подвоев и привоев в зависимости от места их произрастания / В.Г. Николенко, Л.Д. Кондратенко // Садоводство, виноградарство и виноделие Молдавии. - 1979. - № 2. - С. 33-36.

14. Николенко В.Г. Стратификация и закладка прививок пакетно-поддонным способом / В.Г. Николенко // Садоводство, виноградарство и виноделие Молдавии. -1977. -№1.- С. 36-40.

15. Перстнев Н.Д. Виноградарство. - Кишинев, 2001. - 604 с.

16. Радчевский П.П. Влияние гетероауксина на регенерационные свойства виноградных черенков в зависимости от условий освещенности / П.П. Радчевский, М.В. Бессмертная // Политематический сетевой электронный научный журнал Кубанского государственного аграрного университета (Научный журнал КубГАУ) [Электронный ресурс]. - Краснодар: КубГАУ, 2015. - №04(108). С. 379 - 400. - IDA [article ID]: 1081504025. - Режим доступа: http://ej.kubagro.ru/2015/04/pdf/25.pdf, 1,375 у.п.л.

17. Радчевский П.П. Влияние импульсного электромагнитного поля на регенерационную активность черенков винограда сорта Молдова / П.П. Радчевский, В.Ф. Васильченко // Политематический сетевой электронный научный журнал Кубанского государственного аграрного университета (Научный журнал КубГАУ) [Электронный ресурс]. Краснодар: КубГАУ, 2014. - №01(095). С. 347 - 372. - IDA [article ID]: 0951401018.

18. П.П. Радчевский. Влияние обработки виноградных черенков растворами Гетероауксина различной концентрации на их регенерационные свойства // Тр./КубГАУ.-2009.№5 (20). - c. 145-148.

19. Радчевский П.П. Влияние обработки черенков винограда электромагнитным полем на их регенерационные свойства / П.П. Радчевский, Д.Э. Майстер // Политематический сетевой электронный научный журнал Кубанского государственного аграрного университета (Научный журнал КубГАУ) [Электронный ресурс]. - Краснодар: КубГАУ, 2015. - №10(114). С. 1254 1271. - IDA [article ID]: 1141510095. - Режим доступа: http://ej.kubagro.ru/2015/10/pdf/95.pdf, 1,125 у.п.л.

20. П.П. Радчевский. Влияние препарата "Радикс» на регенерационные свойства, выход и качество саженцев // Тр./КубГАУ.-2009.-№4 (19). - с. 90-94.

21. Радчевский П.П. Влияние Радикса плюс на регенерационные свойства черенков винограда сорта восторг в зависимости от их длины / П.П. Радчевский // Политематический сетевой электронный научный журнал Кубанского государственного аграрного университета (Научный журнал КубГАУ) [Электронный ресурс]. - Краснодар: КубГАУ, 2015. - №01(105). С. 266 - 292. - IDA [article ID]: 1051501014. - Режим доступа: http://ej.kubagro.ru/2015/01/pdf/14.pdf, 1,688 у.п.л.

22. Радчевский П.П. Влияние Радикса плюс на регенерационные свойства черенков винограда сорта Молдова в зависимости от их длины / П.П. Радчевский // Политематический сетевой электронный научный журнал Кубанского государственного аграрного университета (Научный журнал КубГАУ) [Электронный ресурс]. - Краснодар: КубГАУ, 2014. - №10(104). С. 375 - 403. - IDA [article ID]: 1041410026. - Режим доступа: http://ej.kubagro.ru/2014/10/pdf/26.pdf, 1,812 у.п.л., импакт-фактор РИНЦ=0,346

23. Радчевский П.П. Влияние Stimolante $66 \mathrm{f}$ на регенерационную активность черенков винограда сорта Молдова, выход и качество саженцев / П.П. Радчевский // Политематический сетевой электронный научный журнал Кубанского государственного аграрного университета (Научный журнал КубГАУ) [Электронный ресурс]. - Краснодар: КубГАУ, 2015. - №01(105). С. 293 - 315. - IDA [article ID]: 1051501015. - Режим доступа: http://ej.kubagro.ru/2015/01/pdf/15.pdf, 1,438 у.п.л.

24. Радчевский П.П. Влияние физиологически активных веществ на выход и качество виноградных саженцев / П.П. Радчевский, К.О. Печкуров, А.Е. Дух //Научн. тр. /Кубан.ГАУ.2002.-Вып. 394 (422).- с. 120-125.

25. Радчевский П.П. К методике изучения регенерационной активности виноградных черенков (научно-исследовательская работа по биологии в средних общеобразовательных школах) / П.П. Радчевский, Т.П. Радчевская // Политематический сетевой электронный 
научный журнал Кубанского государственного аграрного университета (Научный журнал КубГАУ) [Электронный ресурс]. - Краснодар: КубГАУ, 2014. - №07(101). С. 1779 - 1794. IDA [article ID]: 1011407116. - Режим доступа: http://ej.kubagro.ru/2014/07/pdf/116.pdf, 1 у.п.л., импакт-фактор РИНЦ=0,346

26. Радчевский П.П. Корнеобразовательная способность 5-ти глазковых черенков устойчивых сортов винограда при их укоренении на воде / П.П. Радчевский // Политематический сетевой электронный научный журнал Кубанского государственного аграрного университета (Научный журнал КубГАУ) [Электронный ресурс]. - Краснодар: КубГАУ, 2014. - №01(095). С. 310 - 326. - IDA [article ID]: 0951401016. - Режим доступа: http://ej.kubagro.ru/2014/01/pdf/16.pdf, 1,062 у.п.л., импакт-фактор РИНЦ=0,346

27. Радчевский П.П. Метод прогнозирования укореняемости виноградных черенков / П.П. Радчевский, А.Н. Стороженко, Т.П. Радчевская // Политематический сетевой электронный научный журнал Кубанского государственного аграрного университета (Научный журнал КубГАУ) [Электронный ресурс]. - Краснодар: КубГАУ, 2014. - №09(103). С. 379 - 391. - IDA [article ID]: 1031409025. - Режим доступа: http://ej.kubagro.ru/2014/09/pdf/25.pdf, 0,812 у.п.Л., импакт-фактор РИНЦ=0,346

28. Радчевский П.П. Новации виноградарства России. 26. Применение биологически активных веществ Гумата при выращивании виноградного посадочного материала / П.П. Радчевский, Н.Б. Мороз, Л.П. Трошин // Политематический сетевой электронный научный журнал Кубанского государственного аграрного университета (Научный журнал КубГАУ) [Электронный ресурс]. - Краснодар: КубГАУ, 2010. - №06(60). С. 395 - 411. - Шифр Информрегистра: 042100001210142. - Режим доступа: http://ej.kubagro.ru/2010/06/pdf/28.pdf, 1,062 у.п.л.

29. Радчевский П.П. Новации виноградарства России. 24. Применение биологически активного вещества «Радикс» при выращивании виноградного посадочного материала / П.П. Радчевский, В.С. Черкунов, Л.П. Трошин // Политематический сетевой электронный научный журнал Кубанского государственного аграрного университета (Научный журнал КубГАУ) [Электронный ресурс]. - Краснодар: КубГАУ, 2010. - №06(060). С. 358 - 378. Шифр Информрегистра: 042100001210146, IDA [article ID]: 0601006026. - Режим доступа: http://ej.kubagro.ru/2010/06/pdf/26.pdf, 1,312 у.п.л.

30. Радчевский П.П. Новации виноградарства России. 25. Применение биологически активного вещества «Радикс» при предпосадочной обработке черенков и настольных прививок на выход и качество корнесобственных, привитых и вегетирующих саженцев винограда / П.П. Радчевский, Н.Б. Мороз, Л.П. Трошин // Политематический сетевой электронный научный журнал Кубанского государственного аграрного университета (Научный журнал КубГАУ) [Электронный ресурс]. - Краснодар: КубГАУ, 2010. - №66(060). С. 379 - 394. - Шифр Информрегистра: 0421000012\0145, IDA [article ID]: 0601006027. - Режим доступа: http://ej.kubagro.ru/2010/06/pdf/27.pdf, 1 у.п.л.

31. Радчевский П.П. Особенности проявления корреляционных зависимостей между показателями побего- и корнеобразовательной способности виноградных черенков сортов Молдова и Восторг различной длины, под влиянием обработки их Радиксом плюс / П.П. Радчевский // Политематический сетевой электронный научный журнал Кубанского государственного аграрного университета (Научный журнал КубГАУ) [Электронный ресурс]. Краснодар: КубГАУ, 2015. - №01(105). С. 381 - 412. - IDA [article ID]: 1051501021. - Режим доступа: http://ej.kubagro.ru/2015/01/pdf/21.pdf, 2 у.п.л.

32. Радчевский П.П. Особенности проявления корреляционных зависимостей между степенью вызревания черенков устойчивых сортов винограда и их корнеобразовательной способностью / П.П. Радчевский // Политематический сетевой электронный научный журнал Кубанского государственного аграрного университета (Научный журнал КубГАУ) [Электронный ресурс]. - Краснодар: КубГАУ, 2014. - №01(095). С. 327 - 346. - IDA [article ID]: 0951401017. - Режим доступа: http://ej.kubagro.ru/2014/01/pdf/17.pdf, 1,25 у.п.л., импакт-фактор РИНЦ=0,346

33. Радчевский П.П. Особенности проявления регенерационных свойств у виноградных черенков под влиянием обработки их регулятором роста Стимолант 66Ф / П.П. Радчевский, С.В. Ильченко, С.С. Базоян // Политематический сетевой электронный научный журнал 
Кубанского государственного аграрного университета (Научный журнал КубГАУ) [Электронный ресурс]. - Краснодар: КубГАУ, 2015. - №09(113). С. 1426 - 1454. - IDA [article ID]: 1131509100. - Режим доступа: http://ej.kubagro.ru/2015/09/pdf/100.pdf, 1,812 у.п.л.

34. Радчевский П.П. Особенности проявления регенерационных свойств у черенков столовых сортов винограда Молдова и Восторг различной длины, под влиянием обработки их Радиксом плюс / П.П. Радчевский // Политематический сетевой электронный научный журнал Кубанского государственного аграрного университета (Научный журнал КубГАУ) [Электронный ресурс]. - Краснодар: КубГАУ, 2014. - №10(104). С. 404 - 433. - IDA [article ID]: 1041410027. - Режим доступа: http://ej.kubagro.ru/2014/10/pdf/27.pdf, 1,875 у.п.л., импакт-фактор РИНЦ=0,346

35. Радчевский П.П. Особенности проявления регенерационной способности у черенков технических сортов винограда Бианка, Виорика и Ритон / П.П. Радчевский, С.В. Глебова // Политематический сетевой электронный научный журнал Кубанского государственного аграрного университета (Научный журнал КубГАУ) [Электронный ресурс]. - Краснодар: КубГАУ, 2015. - №10(114). С. 1230 - 1253. - IDA [article ID]: 1141510094. - Режим доступа: http://ej.kubagro.ru/2015/10/pdf/94.pdf, 1,5 у.п.л.

36. Радчевский П.П. Особенности проявления регенерационной способности у черенков технических сортов винограда селекции института винограда и вина «Магарач» - Первенец Магарача, Подарок Магарача и Цитронный Магарача / П.П. Радчевский, Е.В. Ачкасова // Политематический сетевой электронный научный журнал Кубанского государственного аграрного университета (Научный журнал КубГАУ) [Электронный ресурс]. - Краснодар: КубГАУ, 2015. - №10(114). С. 1208 - 1229. - IDA [article ID]: 1141510093. - Режим доступа: http://ej.kubagro.ru/2015/10/pdf/93.pdf, 1,375 у.п.л.

37. Радчевский П.П. Влияние сортовых особенностей на регенерационные свойства черенков подвойных сортов винограда при их укоренении / П.П. Радчевский // Политематический сетевой электронный научный журнал Кубанского государственного аграрного университета (Научный журнал КубГАУ) [Электронный ресурс]. - Краснодар: КубГАУ, 2013. - №07(091). С. 1588 - 1619. - IDA [article ID]: 0911307106. - Режим доступа: http://ej.kubagro.ru/2013/07/pdf/106.pdf, 2 у.п.л., импакт-фактор РИНЦ=0,346

38. Радчевский П.П. Особенности протекания регенерационных процессов у черенков винограда сорта молдова в зависимости от их толщины / П.П. Радчевский // Политематический сетевой электронный научный журнал Кубанского государственного аграрного университета (Научный журнал КубГАУ) [Электронный ресурс]. - Краснодар: КубГАУ, 2014. - №03(097). С. 203 - 223. - IDA [article ID]: 0971403014. - Режим доступа: http://ej.kubagro.ru/2014/03/pdf/14.pdf, 1,312 у.п.л., импакт-фактор РИНЦ=0,346

39. Радчевский П.П. Регенерационные свойства виноградных черенков под влиянием обработки их гетероауксином в зависимости от сортовых особенностей / П.П. Радчевский, Л.П. Трошин / // Политематический сетевой электронный научный журнал Кубанского государственного аграрного университета (Научный журнал КубГАУ) [Электронный ресурс]. Краснодар: КубГАУ, 2012. - № 03(77). С. 348 - 360. - Шифр Информрегистра: 042100012\0238. - Режим доступа: http://ej.kubagro.ru/2010/08/pdf/30.pdf.

40. Саркисова М.М. Действие ауксинов на некоторые физиологические изменения в регенерирующих черенках винограда / М.М. Саркисова // Процессы дифференциации и регенерации у изолированных тканей и органов растений (Межвузовский научно-тематический сборник ). - Махачкала, 1986.- с. 49-53.

41. Солодова Н.П. Некоторые особенности технологии выращивания привитых виноградных саженцев в условиях Черноморского побережья Краснодарского края / Н.П. Солодова: Тезисы докладов к научно-технической конференции виноградарей и виноделов Краснодарского края. - Анапа, 1973. - С. 31-39.

42. Трошин Л.П. Районированные сорта винограда России (учебное пособие) / Л.П. Трошин, П.П. Радчевский. - Краснодар: ООО “Вольные мастера”, 2004/2005. -176 с.

43. Унгуряну С.И. О регенерационной способности подвоев / С.И. Унгуряну, 3.А. Гербей // Состояние и перспективы развития виноградарства: Тезисы докладов Республиканской научно-практической конференции (19-20 сентября 1990 г.). - Кишинев, 1990. - С. 42-44. 
44. Чайлахян М.Х., Саркисова М.М. Регуляторы роста у виноградной лозы и плодовых культур. - Ереван: Изд-во АН Армянской ССР, 1980. - 188 с.

45. Эйферт Й. Физиологические и биохимические основы выращивания привитых саженцев / Й. Эйферт, Й. Эйферт // Новое в виноградном питомниководстве ВНР и МССР; Под ред. А.С. Субботовича. - Кишинев: Картя Молдовеняскэ, 1984. - С. 12-33.

46. Чхартишвили Н.С. Влияние мульчирования почвы на корневую систему / Н.С.Чхартишвили, Б.А.Бекаури // Виноделие и виноградарство СССР. - 1979 - №5 - С. 41-42.

\section{References}

1. Aliev N.A. Shirokorjadnye vysokoshtambovye vinogradniki. - Mahachkala: Dag. kn. izd-vo, 1980. - $109 \mathrm{~s}$.

2. Gadzhiev Z.Sh. Shirokorjadnyj sposob vozdelyvanija vinograda / Z.Sh. Gadzhiev // Sadovodstvo, vinogradarstvo i vinodelie Moldavii. - 1979. - № 12. - s. 34-36.

3. Gromakovskij I.K. Po puti intensifikacii vinogradnogo pitomnikovodstva / I.K. Gromakovskij // Intensifikacija proizvodstva vinograda - vazhnyj faktor realizacii prodovol'stvennoj programmy: spisok tezisov dokladov Respublikanskoj konferencii po vinogradarstvu (7.09.1984 g.). - Kishinev, 1984. - S. 18-20.

4. Gudumak F.A. Vlijanie retardantov na rost pobegov, vyhod i regeneracionnuju aktivnost' cherenkov u sorta podvoja vinograda Berlandieri $\times$ Riparia SO -4 / F.A. Gudumak // Sostojanie i perspektivy razvitija vinogradarstva: tez. dokl. Resp. nauch.-prakt. konf. (19-21 sentjabrja 1990 g). Kishinev, 1990.- S. 58-59.

5. Dubinko V.K. Intensivnye sposoby vyrashhivanija vinograda / V.K. Dubinko, V.F. Karzov. Kiev: Urozhaj, 1981. - 96 s.

6. Kazaliev M.M. Vlijanie privoja i podvoja na kachestvo privivok i vyhod sazhencev / M.M. Kazaliev, S.D. Radzhabov, Ja.M. Pejsotov // Vinograd i vino Rossii. - 1997. - №3. - S. 12-14.

7. Lomkaci S.I. Kornevaja sistema vinograda v svjazi s nagruzkoj // Sadovodstvo, vinogradarstvo i vinodelie Moldavii. - 1963. - №2. - S. 32-33.

8. Maltabar L.M. Vinogradnyj pitomnik (teorija i praktika) / L.M. Maltabar, D.M. Kozachenko. - Krasnodar, 2009. - 290 s.

9. Maltabar L.M. Rizogennaja aktivnost' cherenkov novyh sortov vinograda pri okorenenii ih na vode i v briketah iz gravilena / L.M. Maltabar, P.P. Radchevskij, N.D. Magomedov // Vinograd i vino Rossii. - 1996. - №5. - S. 11-13.

10. Martynova I.N. Adaptacija podvojnyh sortov vinograda k uslovijam Nizhnego Pridon'ja. / I.N. Martynova, T.B. Shatilova, N.O. Arestova // Vinograd i vino Rossii. - 1997. - №3. - S. 9-11.

11. Melkonjan A.S. Vlijanie razlichnyh norm nagruzki na moshhnost' molodyh kustov vinograda: avtoref. dis. ... kand. s.-h. nauk. - Odessa, 1958. - 20 s.

12. Mel'nik N.I. Produktivnost' i jeffektivnost' podvojnyh sortov vinograda i privojno-podvojnyh kombinacij v Tamanskoj podzone Anapo-Tamanskoj sel'skohozjajstvennoj zony: avtoref. dis. ... kand. s.-h. nauk. - Krasnodar, 2007 - 25 s.

13. Nikolenko V.G. Vyhod privityh sazhencev po razlichnym kombinacijam podvoev i privoev v zavisimosti ot mesta ih proizrastanija / V.G. Nikolenko, L.D. Kondratenko // Sadovodstvo, vinogradarstvo i vinodelie Moldavii. - 1979. - № 2. - S. 33-36.

14. Nikolenko V.G. Stratifikacija i zakladka privivok paketno-poddonnym sposobom / V.G. Nikolenko // Sadovodstvo, vinogradarstvo i vinodelie Moldavii. -1977. -№1 .- S. 36-40.

15. Perstnev N.D. Vinogradarstvo. - Kishinev, 2001. - 604 s.

16. Radchevskij P.P. Vlijanie geteroauksina na regeneracionnye svojstva vinogradnyh cherenkov v zavisimosti ot uslovij osveshhennosti / P.P. Radchevskij, M.V. Bessmertnaja // Politematicheskij setevoj jelektronnyj nauchnyj zhurnal Kubanskogo gosudarstvennogo agrarnogo universiteta (Nauchnyj zhurnal KubGAU) [Jelektronnyj resurs]. - Krasnodar: KubGAU, 2015. - №04(108). S. 379 - 400. - IDA [article ID]: 1081504025. - Rezhim dostupa: http://ej.kubagro.ru/2015/04/pdf/25.pdf, 1,375 u.p.1.

17. Radchevskij P.P. Vlijanie impul'snogo jelektromagnitnogo polja na regeneracionnuju aktivnost' cherenkov vinograda sorta Moldova / P.P. Radchevskij, V.F. Vasil'chenko // Politematicheskij setevoj jelektronnyj nauchnyj zhurnal Kubanskogo gosudarstvennogo agrarnogo 
universiteta (Nauchnyj zhurnal KubGAU) [Jelektronnyj resurs]. - Krasnodar: KubGAU, 2014. №01(095). S. 347 - 372. - IDA [article ID]: 0951401018.

18. P.P. Radchevskij. Vlijanie obrabotki vinogradnyh cherenkov rastvorami Geteroauksina razlichnoj koncentracii na ih regeneracionnye svojstva // Tr./KubGAU.-2009.-№5 (20). - s. 145-148.

19. Radchevskij P.P. Vlijanie obrabotki cherenkov vinograda jelektromagnitnym polem na ih regeneracionnye svojstva / P.P. Radchevskij, D.Je. Majster // Politematicheskij setevoj jelektronnyj nauchnyj zhurnal Kubanskogo gosudarstvennogo agrarnogo universiteta (Nauchnyj zhurnal KubGAU) [Jelektronnyj resurs]. - Krasnodar: KubGAU, 2015. - №10(114). S. 1254 - 1271. - IDA [article ID]: 1141510095. - Rezhim dostupa: http://ej.kubagro.ru/2015/10/pdf/95.pdf, 1,125 u.p.l.

20. P.P. Radchevskij. Vlijanie preparata "Radiks» na regeneracionnye svojstva, vyhod i kachestvo sazhencev // Tr./KubGAU.-2009.-№4 (19). - s. 90-94.

21. Radchevskij P.P. Vlijanie Radiksa pljus na regeneracionnye svojstva cherenkov vinograda sorta vostorg v zavisimosti ot ih dliny / P.P. Radchevskij // Politematicheskij setevoj jelektronnyj nauchnyj zhurnal Kubanskogo gosudarstvennogo agrarnogo universiteta (Nauchnyj zhurnal KubGAU) [Jelektronnyj resurs]. - Krasnodar: KubGAU, 2015. - №01(105). S. 266 - 292. - IDA [article ID]: 1051501014. - Rezhim dostupa: http://ej.kubagro.ru/2015/01/pdf/14.pdf, 1,688 u.p.1.

22. Radchevskij P.P. Vlijanie Radiksa pljus na regeneracionnye svojstva cherenkov vinograda sorta Moldova v zavisimosti ot ih dliny / P.P. Radchevskij // Politematicheskij setevoj jelektronnyj nauchnyj zhurnal Kubanskogo gosudarstvennogo agrarnogo universiteta (Nauchnyj zhurnal KubGAU) [Jelektronnyj resurs]. - Krasnodar: KubGAU, 2014. - №10(104). S. 375 - 403. - IDA [article ID]: 1041410026. - Rezhim dostupa: http://ej.kubagro.ru/2014/10/pdf/26.pdf, 1,812 u.p.1., impakt-faktor $\mathrm{RINC}=0,346$

23. Radchevskij P.P. Vlijanie Stimolante $66 \mathrm{f}$ na regeneracionnuju aktivnost' cherenkov vinograda sorta Moldova, vyhod i kachestvo sazhencev / P.P. Radchevskij // Politematicheskij setevoj jelektronnyj nauchnyj zhurnal Kubanskogo gosudarstvennogo agrarnogo universiteta (Nauchnyj zhurnal KubGAU) [Jelektronnyj resurs]. - Krasnodar: KubGAU, 2015. - №01(105). S. 293 - 315. IDA [article ID]: 1051501015. - Rezhim dostupa: http://ej.kubagro.ru/2015/01/pdf/15.pdf, 1,438 u.p.l. 24. Radchevskij P.P. Vlijanie fiziologicheski aktivnyh veshhestv na vyhod i kachestvo vinogradnyh sazhencev / P.P. Radchevskij, K.O. Pechkurov, A.E. Duh //Nauchn. tr. /Kuban.GAU.2002.-Vyp. 394 (422).- s. 120-125.

25. Radchevskij P.P. K metodike izuchenija regeneracionnoj aktivnosti vinogradnyh cherenkov (nauchno-issledovatel'skaja rabota po biologii v srednih obshheobrazovatel'nyh shkolah) / P.P. Radchevskij, T.P. Radchevskaja // Politematicheskij setevoj jelektronnyj nauchnyj zhurnal Kubanskogo gosudarstvennogo agrarnogo universiteta (Nauchnyj zhurnal KubGAU) [Jelektronnyj resurs]. - Krasnodar: KubGAU, 2014. - №07(101). S. 1779 - 1794. - IDA [article ID]: 1011407116. - Rezhim dostupa: http://ej.kubagro.ru/2014/07/pdf/116.pdf, 1 u.p.1., impakt-faktor RINC=0,346 26. Radchevskij P.P. Korneobrazovatel'naja sposobnost' 5-ti glazkovyh cherenkov ustojchivyh sortov vinograda pri ih ukorenenii na vode / P.P. Radchevskij // Politematicheskij setevoj jelektronnyj nauchnyj zhurnal Kubanskogo gosudarstvennogo agrarnogo universiteta (Nauchnyj zhurnal KubGAU) [Jelektronnyj resurs]. - Krasnodar: KubGAU, 2014. - №01(095). S. 310 - 326. - IDA [article ID]: 0951401016. - Rezhim dostupa: http://ej.kubagro.ru/2014/01/pdf/16.pdf, 1,062 u.p.l., impakt-faktor RINC $=0,346$

27. Radchevskij P.P. Metod prognozirovanija ukorenjaemosti vinogradnyh cherenkov / P.P. Radchevskij, A.N. Storozhenko, T.P. Radchevskaja // Politematicheskij setevoj jelektronnyj nauchnyj zhurnal Kubanskogo gosudarstvennogo agrarnogo universiteta (Nauchnyj zhurnal KubGAU) [Jelektronnyj resurs]. - Krasnodar: KubGAU, 2014. - №09(103). S. 379 - 391. - IDA [article ID]: 1031409025. - Rezhim dostupa: http://ej.kubagro.ru/2014/09/pdf/25.pdf, 0,812 u.p.1., impakt-faktor $\mathrm{RINC}=0,346$

28. Radchevskij P.P. Novacii vinogradarstva Rossii. 26. Primenenie biologicheski aktivnyh veshhestv Gumata pri vyrashhivanii vinogradnogo posadochnogo materiala / P.P. Radchevskij, N.B. Moroz, L.P. Troshin // Politematicheskij setevoj jelektronnyj nauchnyj zhurnal Kubanskogo gosudarstvennogo agrarnogo universiteta (Nauchnyj zhurnal KubGAU) [Jelektronnyj resurs]. Krasnodar: KubGAU, 2010. - №06(60). S. 395 - 411. - Shifr Informregistra: 042100001210142. Rezhim dostupa: http://ej.kubagro.ru/2010/06/pdf/28.pdf, 1,062 u.p.1. 
29. Radchevskij P.P. Novacii vinogradarstva Rossii. 24. Primenenie biologicheski aktivnogo veshhestva «Radiks» pri vyrashhivanii vinogradnogo posadochnogo materiala / P.P. Radchevskij, V.S. Cherkunov, L.P. Troshin // Politematicheskij setevoj jelektronnyj nauchnyj zhurnal Kubanskogo gosudarstvennogo agrarnogo universiteta (Nauchnyj zhurnal KubGAU) [Jelektronnyj resurs]. Krasnodar: KubGAU, 2010. - №06(060). S. 358 - 378. - Shifr Informregistra: 0421000012\0146, IDA [article ID]: 0601006026. - Rezhim dostupa: http://ej.kubagro.ru/2010/06/pdf/26.pdf, 1,312 u.p.1. 30. Radchevskij P.P. Novacii vinogradarstva Rossii. 25. Primenenie biologicheski aktivnogo veshhestva «Radiks» pri predposadochnoj obrabotke cherenkov i nastol'nyh privivok na vyhod i kachestvo kornesobstvennyh, privityh i vegetirujushhih sazhencev vinograda / P.P. Radchevskij, N.B. Moroz, L.P. Troshin // Politematicheskij setevoj jelektronnyj nauchnyj zhurnal Kubanskogo gosudarstvennogo agrarnogo universiteta (Nauchnyj zhurnal KubGAU) [Jelektronnyj resurs]. Krasnodar: KubGAU, 2010. - №06(060). S. 379 - 394. - Shifr Informregistra: 042100001210145, IDA [article ID]: 0601006027. - Rezhim dostupa: http://ej.kubagro.ru/2010/06/pdf/27.pdf, 1 u.p.l.

31. Radchevskij P.P. Osobennosti projavlenija korreljacionnyh zavisimostej mezhdu pokazateljami pobego- i korneobrazovatel'noj sposobnosti vinogradnyh cherenkov sortov Moldova i Vostorg razlichnoj dliny, pod vlijaniem obrabotki ih Radiksom pljus / P.P. Radchevskij // Politematicheskij setevoj jelektronnyj nauchnyj zhurnal Kubanskogo gosudarstvennogo agrarnogo universiteta (Nauchnyj zhurnal KubGAU) [Jelektronnyj resurs]. - Krasnodar: KubGAU, 2015. №01(105). S. 381 - 412. - IDA [article ID]: 1051501021. - Rezhim dostupa: http://ej.kubagro.ru/2015/01/pdf/21.pdf, 2 u.p.l.

32. Radchevskij P.P. Osobennosti projavlenija korreljacionnyh zavisimostej mezhdu stepen'ju vyzrevanija cherenkov ustojchivyh sortov vinograda i ih korneobrazovatel'noj sposobnost'ju / P.P. Radchevskij // Politematicheskij setevoj jelektronnyj nauchnyj zhurnal Kubanskogo gosudarstvennogo agrarnogo universiteta (Nauchnyj zhurnal KubGAU) [Jelektronnyj resurs]. - Krasnodar: KubGAU, 2014. - №01(095). S. 327 - 346. - IDA [article ID]: 0951401017. - Rezhim dostupa:

http://ej.kubagro.ru/2014/01/pdf/17.pdf, 1,25 u.p.l., impakt-faktor RINC=0,346

33. Radchevskij P.P. Osobennosti projavlenija regeneracionnyh svojstv u vinogradnyh cherenkov pod vlijaniem obrabotki ih reguljatorom rosta Stimolant 66F / P.P. Radchevskij, S.V. Il'chenko, S.S. Bazojan // Politematicheskij setevoj jelektronnyj nauchnyj zhurnal Kubanskogo gosudarstvennogo agrarnogo universiteta (Nauchnyj zhurnal KubGAU) [Jelektronnyj resurs]. - Krasnodar: KubGAU, 2015. - №09(113). S. 1426 - 1454. - IDA [article ID]: 1131509100. - Rezhim dostupa: http://ej.kubagro.ru/2015/09/pdf/100.pdf, 1,812 u.p.l.

34. Radchevskij P.P. Osobennosti projavlenija regeneracionnyh svojstv u cherenkov stolovyh sortov vinograda Moldova i Vostorg razlichnoj dliny, pod vlijaniem obrabotki ih Radiksom pljus / P.P. Radchevskij // Politematicheskij setevoj jelektronnyj nauchnyj zhurnal Kubanskogo gosudarstvennogo agrarnogo universiteta (Nauchnyj zhurnal KubGAU) [Jelektronnyj resurs]. - Krasnodar: KubGAU, 2014. - №10(104). S. 404 - 433. - IDA [article ID]: 1041410027. - Rezhim dostupa:

http://ej.kubagro.ru/2014/10/pdf/27.pdf, 1,875 u.p.1., impakt-faktor RINC=0,346

35. Radchevskij P.P. Osobennosti projavlenija regeneracionnoj sposobnosti u cherenkov tehnicheskih sortov vinograda Bianka, Viorika i Riton / P.P. Radchevskij, S.V. Glebova // Politematicheskij setevoj jelektronnyj nauchnyj zhurnal Kubanskogo gosudarstvennogo agrarnogo universiteta (Nauchnyj zhurnal KubGAU) [Jelektronnyj resurs]. - Krasnodar: KubGAU, 2015. №10(114). S. 1230 - 1253. - IDA [article ID]: 1141510094. - Rezhim dostupa: http://ej.kubagro.ru/2015/10/pdf/94.pdf, 1,5 u.p.l.

36. Radchevskij P.P. Osobennosti projavlenija regeneracionnoj sposobnosti u cherenkov tehnicheskih sortov vinograda selekcii instituta vinograda i vina «Magarach» - Pervenec Magaracha, Podarok Magaracha i Citronnyj Magaracha / P.P. Radchevskij, E.V. Achkasova // Politematicheskij setevoj jelektronnyj nauchnyj zhurnal Kubanskogo gosudarstvennogo agrarnogo universiteta (Nauchnyj zhurnal KubGAU) [Jelektronnyj resurs]. - Krasnodar: KubGAU, 2015. - №10(114). S. 1208 - 1229. - IDA [article ID]: 1141510093. - Rezhim dostupa:

http://ej.kubagro.ru/2015/10/pdf/93.pdf, 1,375 u.p.l.

37. Radchevskij P.P. Vlijanie sortovyh osobennostej na regeneracionnye svojstva cherenkov podvojnyh sortov vinograda pri ih ukorenenii / P.P. Radchevskij // Politematicheskij setevoj jelektronnyj nauchnyj zhurnal Kubanskogo gosudarstvennogo agrarnogo universiteta (Nauchnyj zhurnal KubGAU) [Jelektronnyj resurs]. - Krasnodar: KubGAU, 2013. - №07(091). S. 1588 - 1619. - 
IDA [article ID]: 0911307106. - Rezhim dostupa: http://ej.kubagro.ru/2013/07/pdf/106.pdf, 2 u.p.l., impakt-faktor RINC $=0,346$

38. Radchevskij P.P. Osobennosti protekanija regeneracionnyh processov u cherenkov vinograda sorta moldova v zavisimosti ot ih tolshhiny / P.P. Radchevskij // Politematicheskij setevoj jelektronnyj nauchnyj zhurnal Kubanskogo gosudarstvennogo agrarnogo universiteta (Nauchnyj zhurnal KubGAU) [Jelektronnyj resurs]. - Krasnodar: KubGAU, 2014 - №03(097). S. 203 - 223. - IDA [article ID]: 0971403014. - Rezhim dostupa: http://ej.kubagro.ru/2014/03/pdf/14.pdf, 1,312 u.p.1., impakt-faktor RINC $=0,346$

39. Radchevskij P.P. Regeneracionnye svojstva vinogradnyh cherenkov pod vlijaniem obrabotki ih geteroauksinom v zavisimosti ot sortovyh osobennostej / P.P. Radchevskij, L.P. Troshin / //

Politematicheskij setevoj jelektronnyj nauchnyj zhurnal Kubanskogo gosudarstvennogo agrarnogo universiteta (Nauchnyj zhurnal KubGAU) [Jelektronnyj resurs]. - Krasnodar: KubGAU, 2012 . - № 03(77). S. 348 - 360. - Shifr Informregistra: 04210001210238. - Rezhim dostupa:

http://ej.kubagro.ru/2010/08/pdf/30.pdf.

40. Sarkisova M.M. Dejstvie auksinov na nekotorye fiziologicheskie izmenenija v regenerirujushhih cherenkah vinograda / M.M. Sarkisova // Processy differenciacii i regeneracii u izolirovannyh tkanej i organov rastenij (Mezhvuzovskij nauchno-tematicheskij sbornik ). Mahachkala, 1986.- s. 49-53.

41. Solodova N.P. Nekotorye osobennosti tehnologii vyrashhivanija privityh vinogradnyh sazhencev v uslovijah Chernomorskogo poberezh'ja Krasnodarskogo kraja / N.P. Solodova: Tezisy dokladov k nauchno-tehnicheskoj konferencii vinogradarej i vinodelov Krasnodarskogo kraja. Anapa, 1973. - S. 31-39.

42. Troshin L.P. Rajonirovannye sorta vinograda Rossii (uchebnoe posobie) / L.P. Troshin, P.P. Radchevskij. - Krasnodar: OOO "Vol'nye mastera", 2004/2005. -176 s.

43. Ungurjanu S.I. O regeneracionnoj sposobnosti podvoev / S.I. Ungurjanu, Z.A. Gerbej // Sostojanie i perspektivy razvitija vinogradarstva: Tezisy dokladov Respublikanskoj nauchnoprakticheskoj konferencii (19-20 sentjabrja 1990 g.). - Kishinev, 1990. - S. $42-44$.

44. Chajlahjan M.H., Sarkisova M.M. Reguljatory rosta u vinogradnoj lozy i plodovyh kul'tur. Erevan: Izd-vo AN Armjanskoj SSR, 1980. - 188 s.

45. Jejfert J. Fiziologicheskie i biohimicheskie osnovy vyrashhivanija privityh sazhencev / J. Jejfert, J. Jejfert // Novoe v vinogradnom pitomnikovodstve VNR i MSSR; Pod red. A.S. Subbotovicha. - Kishinev: Kartja Moldovenjaskje, 1984. - S. 12-33.

46. Chhartishvili N.S. Vlijanie mul'chirovanija pochvy na kornevuju sistemu / N.S.Chhartishvili, B.A.Bekauri // Vinodelie i vinogradarstvo SSSR. - 1979 - №5 - S. 41-42. 